Primljen / Received: 10.6.2019.

Ispravljen / Corrected: 22.9.2019.

Prihvaćen / Accepted: 3.10.2018.

Dostupno online / Available online: 10.10.2019.

\title{
Assessment of reinforcement corrosion and concrete damage on bridges using non-destructive testing
}

Authors:

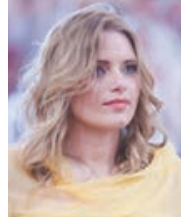

Assist.Prof. Marija Kušter Marić marijak@grad.hr

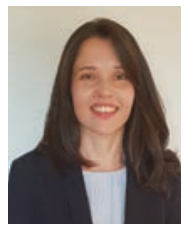

Assoc.Prof. Ana Mandić Ivanković mandicka@grad.hr
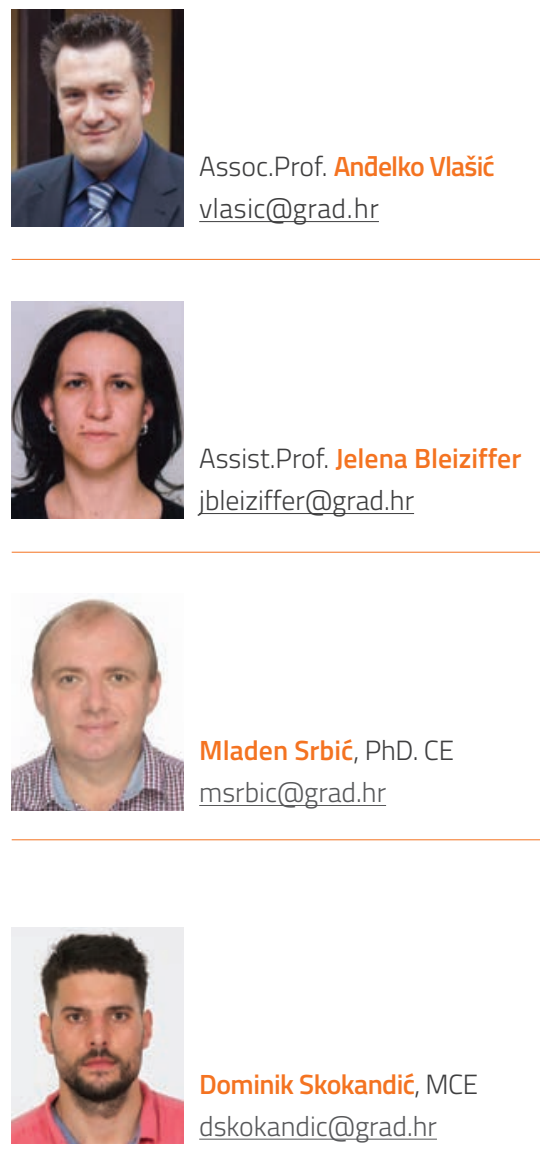

University of Zagreb Faculty of Civil Engineering Department of Structural Engineering
Marija Kušter Marić, Ana Mandić Ivanković, Andelko Vlašić, Jelena Bleiziffer,

Preliminary note Mladen Srbić, Dominik Skokandić

\section{Assessment of reinforcement corrosion and concrete damage on bridges using non-destructive testing}

Management of bridges in Croatia and their vulnerability to reinforcement corrosion is discussed in the paper. New maintenance approach, where visual inspections are combined with the non-destructive testing methods, is proposed and demonstrated on six representative bridges. Using this methodology, reinforcement corrosion on structural elements may be detected earlier and more precisely. Obtained results as well as correlations between different measured parameters are important input parameters for prediction of future degradation of structures and decision making for future maintenance activity.
Key words:
crack geometry, concrete strength, concrete cover, electrical resistivity, half-cell potential

Prethodno priopćenje

Marija Kušter Marić, Ana Mandić Ivanković, Andelko Vlašić, Jelena Bleiziffer,

Mladen Srbić, Dominik Skokandić

\section{Ocjenjivanje korozije armature i oštećenja betona na mostovima primjenom nerazornih ispitivanja}

U radu se raspravlja o gospodarenju mostovima u Hrvatskoj i njihovoj osjetljivosti na koroziju armature. Predlaže se, te na šest reprezentativnih mostova i razrađuje, novi pristup održavanju u kojemu se vizualni pregledi kombiniraju s nerazornim metodama. Koristeći tu metodologiju, moguće je ranije i točnije otkriti koroziju armature u konstrukcijskim elementima. Dobiveni rezultati i korelacije između različitih mjerenih parametara važni su ulazni podaci za predviđanje budućeg propadanja konstrukcije i odlučivanje o budućim aktivnostima održavanja.

\section{Ključne riječi:}

geometrija pukotine, čvrstoća betona, zaštitni sloj betona, električna otpornost, polućelijasti potencijal

Marija Kušter Marić, Ana Mandić Ivanković, Anđelko Vlašić, Jelena Bleiziffer,

Vorherige Mitteilung

Mladen Srbić, Dominik Skokandić

\section{Bewertung von Bewehrungskorrosion und Betonschäden an Brücken durch zerstörungsfreie Prüfung}

Das Management von Brücken in Kroatien und ihre Anfälligkeit für Bewehrungskorrosion werden in dem Papier erörtert. An sechs repräsentativen Brücken wird ein neuer Wartungsansatz vorgeschlagen und demonstriert, bei dem Sichtprüfungen mit den zerstörungsfreien Prüfmethoden kombiniert werden. Mit dieser Methode kann Bewehrungskorrosion an Strukturelementen früher und genauer erkannt werden. Erhaltene Ergebnisse sowie Korrelationen zwischen verschiedenen gemessenen Parametern sind wichtige Eingabeparameter für die Vorhersage zukünftiger Verschlechterungen von Strukturen und die Entscheidungsfindung für zukünftige Instandhaltungstätigkeiten.

Schlüsselwörter:

Rissgeometrie, Betonfestigkeit, Betondeckung, spezifischer elektrischer Widerstand, Halbzellenpotential 


\section{Introduction}

The vast majority of infrastructure, e.g. bridges, buildings, tunnels, dams, is made of concrete. More than $90 \%$ of bridges on Croatian state roads are made of reinforced or prestressed concrete [1] and similar distribution according to the construction materials applies to the bridges on other roads in Croatia, but also worldwide. According to the Croatian National Annex HRN EN 1990:2011/NA:2011 to the European standard HRN EN $1990: 2011$ [2], design service life is 50 years for bridges of normal level of importance and/or standard size; and 100 years for bridges of high importance and/or large scale. With regular maintenance of the bridge, the structure reliability should be above the minimum permissible level during that prescribed time. However, many concrete bridges are in poor condition as soon as after 20 to 30 years of service and cannot achieve designed service life without complex and expensive repairs due to the structural and material degradation [3]. The causes of bridge deterioration and shortening of its service life are: errors and negligence during design, poor construction quality, lack of maintenance, degradation mechanism caused by aggressive environment, increasing service load and hazards, and very often a combination of several of the aforementioned causes [4-15]. Corrosion of embedded reinforcement is the most prevalent form of degradation of reinforced concrete (RC) structures, especially bridges exposed to the sea and/or de-icing salts. Corrosion process in RC structures is recognized by brown patches of rust that emerge on the concrete surface and/or cracked concrete cover. Chloride-induced corrosion of steel in concrete decreases durability as well as load-bearing capacity and serviceability of the structure [16-24]. Moreover, under special circumstances it may lead to collapse of prestressed concrete structure caused by brittle fracture of corroded tendons [25]. Cracks and concrete damage caused by other mechanical and non-mechanical processes additionally accelerate corrosion processes and cause progressive deterioration of structures $[6,7]$.

Visual inspection is the most used method to evaluate bridge condition and a basis for maintenance plan, but reinforcement corrosion can be visually observed only in advanced stage. Hence, use of non-destructive testing as a supplement to visual inspection is investigated on six case studies in the framework of this research in order to achieve higher objectivity in bridge structure evaluation and to detect corrosion vulnerability before visible damage and/or to more precisely evaluate structure condition. Moreover, to achieve proactive maintenance of bridges, it is necessary to predict future structure condition using numerical models for service life prediction, where the results of non-destructive testing can be used for calibration and verification of models $[26,27]$.

\section{Bridge management in Croatia}

Five road authorities responsible for management, construction and maintenance of approximately 3500 bridges, including overpasses and underpasses on different type of roads in Croatia, are included in this research (Table 1) [26]. They all have an updated bridge inventory, but the bridge management systems (BMS) have been established only by Croatian Motorways and Croatian Roads [1, 26].

Bridge management system for Croatian Motorways and Croatian Roads both have an adequate algorithm to evaluate condition of each structural element based on the comprehensive data on detected damage. The algorithm of Croatian Motorways is stored in a computer system, while the algorithm of Croatian Roads is still on a manual basis $[1,26]$. Condition assessment of structural elements of other road bridges is conducted by an inspector without standardized procedure for visual inspection and the results are less objective, especially for bridges on the roads of lower classes (county, local and un-classified roads) [1, 26].

Besides natural hazards (flood, landslide, earthquake, vehicle impact and boat collision) followed by non-periodical visual inspection; results of periodical visual inspection are basis for development of bridge maintenance program and making decisions on non-regular maintenance (repair, strengthening and reconstruction) [1]. Special visual inspection, complemented by testing on a structure and/or in a laboratory, are usually carried out after decision on required increased maintenance, in order to define scope and complexity of rehabilitation work [26].

Most of the road authorities develop a maintenance plan for only one year in advance based on the four-year programme for maintenance of public roads. Moreover, they do not provide the deterioration forecasting modelling and sufficient analyses on structure deterioration over time. Only exceptions from this practice are large and significant bridges and a preliminary analysis on bridges on national roads [28].

\subsection{Vulnerability of bridges to chloride-induced reinforcement corrosion}

Concrete bridges exposed to chlorides from de-icing salts and/ or maritime environment are particularly vulnerable to chlorideinduced reinforcement corrosion. Although Croatia has three types of climate: continental, snow forest and Mediterranean, temperature below freezing point and snow are possible on all Croatian roads, even at the southernmost and warmest regions like Dubrovnik.

Sodium chloride $(\mathrm{NaCl})$ and calcium chloride $\left(\mathrm{CaCl}_{2}\right)$ with neither sand nor fine gravel are used as de-icing salts on the national roads and the motorways. There are two ways of spreading salts on roads: preventive and curative. Preventing salting is performed: - on wet road pavement, when the air temperature suddenly drops to $0^{\circ} \mathrm{C}$

- just before the start of a snow fall

- on dry or wet roads when freezing rain is expected or predicted.

Curative salting is performed when road adhesion is reduced, and dry or moistened salts can be used depending on the road 
Table 1. Bridge management policy used by the road authorities included in the research [26]

\begin{tabular}{|c|c|c|c|c|c|}
\hline Road authority & $\begin{array}{l}\text { Croatian } \\
\text { Motorways }\end{array}$ & $\begin{array}{l}\text { Rijeka- Zagreb } \\
\text { Motorway }\end{array}$ & Croatian Roads & City of Zagreb & $\begin{array}{l}\text { County roads of } \\
\text { Krapina-Zagorje } \\
\text { County }\end{array}$ \\
\hline $\begin{array}{l}\text { Total length of road } \\
\text { network }[\mathrm{km}]\end{array}$ & $\begin{array}{c}2 \times 920.5 \\
\text { (full motorway } \\
\text { profile) }\end{array}$ & $\begin{array}{c}2 \times 175.0 \\
\text { (full motorway profile) }\end{array}$ & 7129.62 & 2589.00 & 661.23 \\
\hline Road classification & Motorways & Motorways & National roads & Unclassified roads & County and local roads \\
\hline Number of bridges & $1213(\mathrm{~L}>5 \mathrm{~m})$ & $\begin{array}{c}75 \text { large bridges; } \\
>100 \text { overpasses, } \\
\text { underpasses and other } \\
\text { passages/crosses }\end{array}$ & $\approx 1800(\mathrm{~L}>2 \mathrm{~m})$ & $\approx 228(\mathrm{~L}>2 \mathrm{~m})$ & $70(\mathrm{~L}>5 \mathrm{~m})$ \\
\hline $\begin{array}{l}\text { Duration of the program } \\
\text { for investment in the } \\
\text { maintenance }\end{array}$ & 1 year & $1-2$ years & 4 years & 1 year & 1 year \\
\hline $\begin{array}{l}\text { Updated bridge } \\
\text { inventory }\end{array}$ & Yes & Yes & Yes & Yes & Yes \\
\hline $\begin{array}{l}\text { Bridge management } \\
\text { system }\end{array}$ & Yes, since 2008 & No & $\begin{array}{l}\text { Yes, since 1996, } \\
\text { updated in } 2001\end{array}$ & No & No \\
\hline $\begin{array}{l}\text { Basis for decision on } \\
\text { repairs, reconstruction } \\
\text { or demolition of bridges }\end{array}$ & $\begin{array}{l}\text { Periodical visual } \\
\text { inspection; } \\
\text { Hazards followed } \\
\text { by non-periodical } \\
\text { visual inspection }\end{array}$ & $\begin{array}{c}\text { Periodical visual } \\
\text { inspection; } \\
\text { Hazards followed by } \\
\text { non-periodical visual } \\
\text { inspection }\end{array}$ & $\begin{array}{l}\text { Periodical visual } \\
\text { inspection; } \\
\text { Hazards followed } \\
\text { by non-periodical } \\
\text { visual inspection }\end{array}$ & $\begin{array}{l}\text { Periodical visual } \\
\text { inspection; } \\
\text { Hazards followed } \\
\text { by non-periodical } \\
\text { visual inspection }\end{array}$ & $\begin{array}{c}\text { Periodical visual } \\
\text { inspection; } \\
\text { Hazards followed by } \\
\text { non-periodical visual } \\
\text { inspection }\end{array}$ \\
\hline $\begin{array}{l}\text { Developed standardized } \\
\text { procedure for visual } \\
\text { inspection of bridges }\end{array}$ & Yes & Yes & Yes & No & No \\
\hline \multicolumn{6}{|c|}{ Type and frequency of periodical visual inspection of bridges } \\
\hline $\begin{array}{c}\text { Routine - regular road } \\
\text { patrol }\end{array}$ & $\min 3 x /$ day & $\min 3 x /$ day & $\min 1 x /$ day & $\mathrm{n} / \mathrm{a}$ & $\min 3 x /$ day \\
\hline $\begin{array}{l}\text { Seasonal visual } \\
\text { inspection }\end{array}$ & $2 x /$ year & 2x/year & - & - & 2x/year \\
\hline Annual visual inspection & - & - & $1 \mathrm{x} / 2$ years & $1 x / 2$ years & - \\
\hline Main visual inspection & $1 \mathrm{x} / 6$ years & $1 \mathrm{x} / 6$ years & $1 \mathrm{x} / 6$ years & $1 \mathrm{x} / 6$ years & $1 \times / 6$ years \\
\hline
\end{tabular}

condition. Salts, moistened by sodium chloride or calcium chloride solution, are used under the following conditions: frozen roadway, increased humidity in the air and low temperatures, freezing and thawing cycles, low mist and rain that falls on the undercooled road pavement, frozen sticking snow, wet pavement conditions indicating the possibility of icing and all the aforementioned factors in combination with a crosswind. Seasonal de-icing salt consumption per unit of road network length on motorways and national roads in the last decade are shown on Figure1 based on the analysis of data obtained from the road authorities. The average seasonal consumption of de-icing salts per unit length of national road for both traffic directions (two lanes) is $5.0 \mathrm{t} / \mathrm{km}$. The average seasonal consumption of de-icing salts per unit length of each separate carriageway on motorway (two lanes) is $16.65 \mathrm{t} / \mathrm{km}$ for Croatian Motorways and 32.08 t/km for Rijeka - Zagreb Motorway. The 34.9-kilometre-long A6 motorway section Vrata - Vrbovsko with the most pronounced winter conditions, operated by Rijeka
- Zagreb Motorway, has the average seasonal consumption of de-icing salts per unit length of each separate carriageway on motorway (two lanes) of even $62.12 \mathrm{t} / \mathrm{km}$.

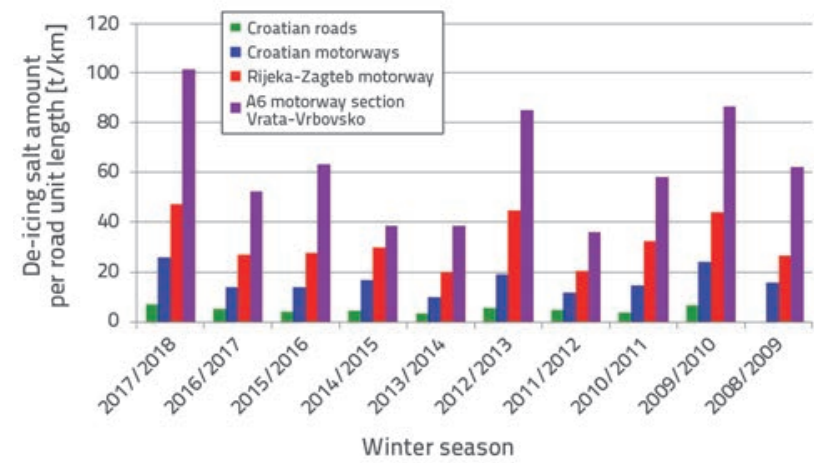

Figure 1. Seasonal de-icing salt consumption per unit length of national roads ( 2 lanes) and per unit length of one carriageway of motorways ( 2 lanes) in the last decade 
During the mild and moderate winter conditions, e.g. temperature below $0^{\circ} \mathrm{C}$ with fog and frost, salting of national roads is performed once a day, while on the motorways once or twice per day. The difference in the frequency of salting between national roads and motorways is more pronounced during the harsh winter conditions: salt is spread on national roads twice per day, while on motorways four to even eight times per day. Higher vehicles speeds on motorways contribute to a more intensive and wider spreading of airborne de-icing salt. Hence, it is not surprising that bridges and overpasses on motorways are more vulnerable to chloride-induced corrosion comparing to structures on roads of lower classes without intensive traffic [3]. Adriatic coast provides an extremely aggressive maritime environment to concrete structures, especially at the location of the large span reinforced concrete arch bridges: Krk Bridge, Pag Bridge and Maslenica Bridge due to the combination of the following phenomena [8, 14, 30]:

- relatively high salinity of the Adriatic Sea of 3.5-3.8 \% of water mass

- strong Bora wind causing salt spray and depositing chlorides on all structural elements

- hot summers, with the maximum annual air temperature up to $37^{\circ} \mathrm{C}$ accelerating the chlorides penetration in concrete

- 10-15 cycles of freezing and thawing per year

- the average annual value of relative air humidity of $71 \%$ favourable for steel corrosion in concrete.

Corrosion of steel reinforcement in concrete consists of two stages (Figure 2): initiation and propagation [21, 31, 32].

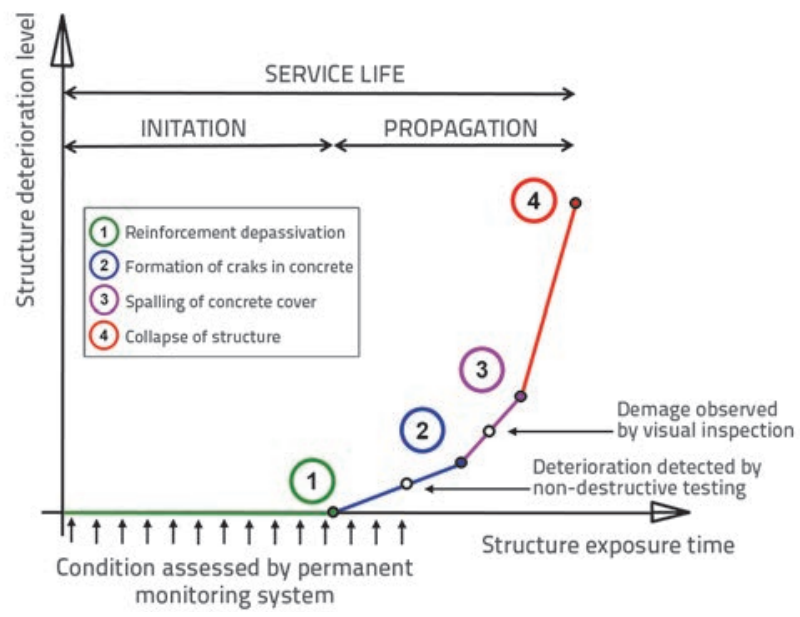

Figure 2. Structure deterioration due to reinforcement corrosion and possible assessment methods (reproduced and modified from $[21,29]$

Initiation phase is characterized by penetration of chlorides in concrete and ends with depassivation of steel rebar by reaching the threshold concentration of free chloride ions in concrete pore solution in contact with the steel surface. Propagation phase includes electrochemical processes of dissolution of iron, which directly leads to a reduction of reinforcement cross section, and formation of corrosion products (rust). The volume of corrosion products is 2 to 7 times greater than the volume of reactants, which results in local concrete cracking and reduction of bond between concrete and rebar [14, 33]. Development of cracks in concrete and reduction of bond between concrete and reinforcement leads to concrete cover delamination.

Reinforcement corrosion in concrete can be observed by visual inspection only in advanced stage [26]. Namely, before reinforcement depassivation there is no corrosion induced damage, while damage at the beginning of propagation, in forms of concrete micro-cracks, is hardly detected without special equipment. Also, visual inspection, as the main tool for bridge condition evaluation, is based on subjective decision of an inspector, which may vary a lot due to the different levels of knowledge and experience [1].

\subsection{Impact of concrete damage on reinforcement corrosion}

Undamaged, good quality concrete with sufficient concrete cover depth acts as a physical barrier which protects passive film of steel reinforcement from depassivation caused by reaching chloride threshold content in concrete at the reinforcement level. Furthermore, cracked concrete cover enables faster chloride penetration to the reinforcement level, which shortens the depassivation time, while in propagation phase allows enough amounts of oxygen on the anodic and cathodic parts of reinforcement, resulting in the higher corrosion rate.

Influence of cracks on chloride penetration in concrete has been extensively investigated on specimens in laboratory conditions, where experimentally determined diffusivity of cracked concrete, with crack width varying from $0.2 \mathrm{~mm}$ to $0.4 \mathrm{~mm}$, is 10 to $10^{3}$ times higher than in un-cracked concrete of the same quality [3437]. However, limited amount of research is available aiming at quantifying the influence of the concrete cracks, as well as other defects, on the reinforcement corrosion in existing structures in real environment, followed by numerical analysis [38, 39].

\section{Bridge case studies}

The proposed methodology of novel pro-active maintenance program, where visual inspection is combined with the nondestructive testing to measure material, structural and corrosion related performance indicators and to determine their interaction, is demonstrated on six concrete road bridges of different type, age, material and traffic demands (Table 2, Figure 3) $[26,27]$. Maslenica Bridge on the motorway and Pag Bridge on the national road are exposed to maritime environment, while other bridges are located in continental climate.

For each bridge, a preliminary visual inspection is performed to detect damage (cracks) on structural members, and thus identify the locations for NDT. Measuring locations are distributed among the bridge portions that can be accessed without special platforms, but in such a manner to include different structural members, i.e. columns, abutments, deviators, hangers and girders. Moreover, the locations are selected in a way to include 
Table 2. Basic data on case studies bridges $[26,27]$

\begin{tabular}{|c|c|c|c|c|c|c|}
\hline Bridge & $\begin{array}{l}\text { Maslenica } \\
\text { Bridge }\end{array}$ & Pag Bridge & Žeinci Bridge & Adriatic Bridge & Bridge of Youth & Homeland Bridge \\
\hline Open to traffic & 1997 & 1968 & 1913 & 1981 & 1974 & 2006 \\
\hline Type of bridge & Deck arch & Deck arch & Tied arch & Continuous girder & Continuous girder & $\begin{array}{c}\text { Extradosed prestressed } \\
\text { girder }\end{array}$ \\
\hline Main span [m] & 200 & 193,20 & 24,50 & 63 & 66 & 120 \\
\hline Length [m] & 374,74 & 279,6 & 24,5 & 479 & 294 & 879 \\
\hline Width [m] & 20,40 & 9,0 & 6,0 & 36,8 & 36,5 & 34 \\
\hline 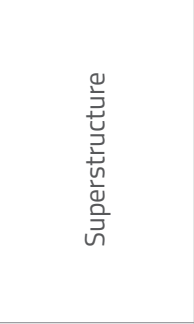 & $\begin{array}{l}8 \text { prestressed } \\
\text { concrete T } \\
\text { girders + RC slab }\end{array}$ & $\begin{array}{c}2 \text { steel } \\
\text { continuous } \\
\text { girders + } \\
\text { orthotropic deck } \\
\text { plate }\end{array}$ & $\begin{array}{c}\text { Grillage system } \\
\text { of longitudinal } \\
\text { and transverse } \\
\text { RC beams + RC } \\
\text { slab }\end{array}$ & $\begin{array}{c}12 \text { prestressed } \\
\text { concrete I girders + } \\
\text { RC slab }\end{array}$ & $\begin{array}{l}\text { Main bridge:2 } \\
\text { steel box girders + } \\
\text { RC "slab" } \\
\text { Approaching } \\
\text { viaducts: grillage } \\
\text { system of } \\
\text { longitudinal PC } \\
\text { and transverse RC } \\
\text { girders + RC slab }\end{array}$ & $\begin{array}{l}\text { Externally prestressed } \\
\text { concrete box girder + } \\
\text { transversely prestressed } \\
\text { concrete slab }\end{array}$ \\
\hline $\begin{array}{l}\text { Type of } \\
\text { binders }\end{array}$ & $\begin{array}{l}\text { Portland cement } \\
\text { PC } 45 \text { with } \\
30 \% \text { slag }\end{array}$ & $\begin{array}{l}\text { Portland cement } \\
\text { PC } 350\end{array}$ & unknown & unknown & unknown & unknown \\
\hline $\begin{array}{l}\text { Year of last } \\
\text { repair }\end{array}$ & 2017. & 1999. & - & - & $\begin{array}{l}\text { 2010.* } \\
\text { (*pristupni vijadukti) }\end{array}$ & 2012. \\
\hline
\end{tabular}

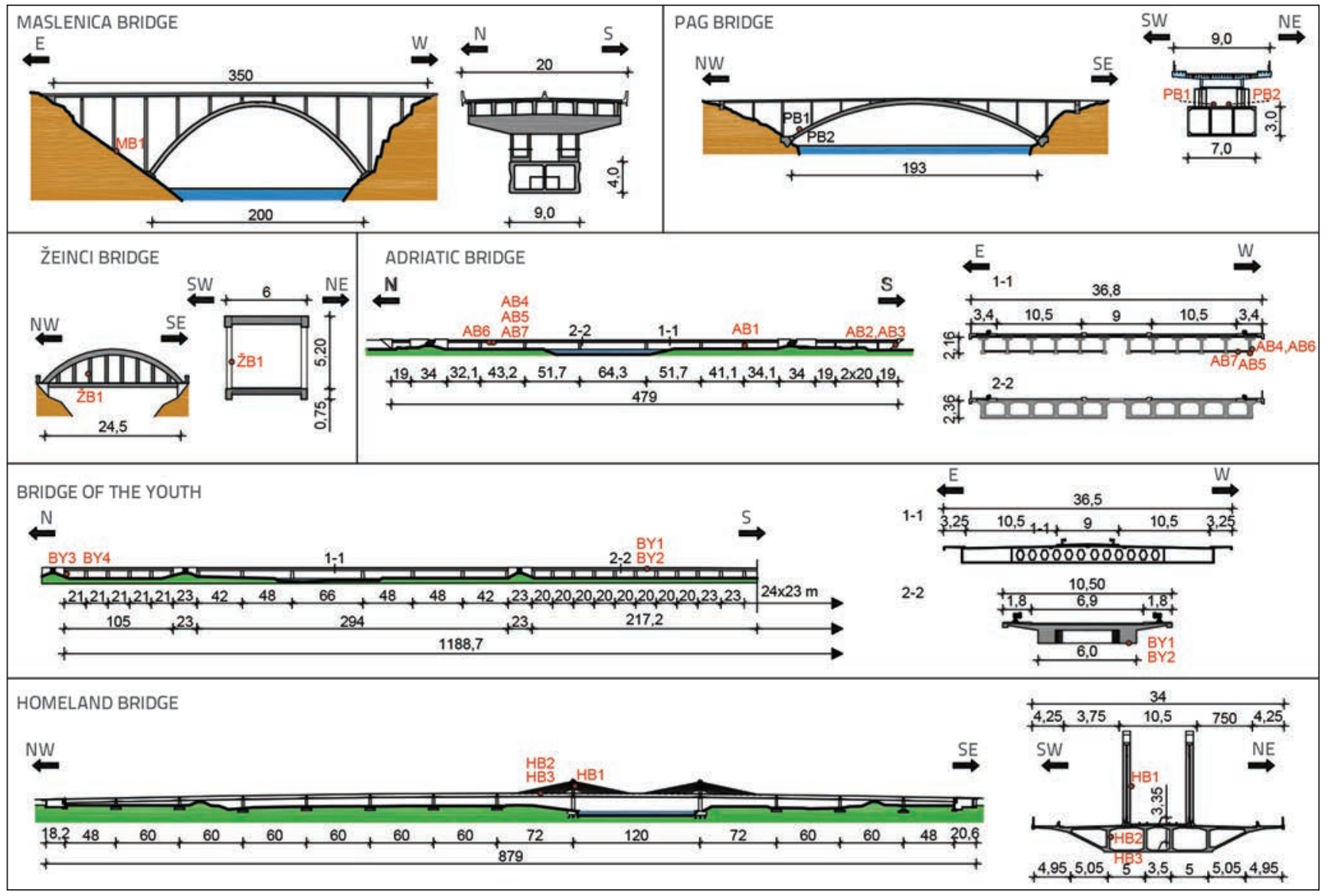

Figure 3. Case studies: bridges layouts with specified measuring locations 
different causes of concrete damage and cracks: shrinkage, settlement, thermal action, errors in design and detailing, overload, reinforcement corrosion etc.

\subsection{Maslenica Bridge}

Maslenica Bridge on the A1 motorway is located on the Adriatic coast crossing Novsko Ždrilo strait characterized by very harsh micro-climate. During the design of the Maslenica Bridge special attention was given to durability issues:

- application of a numerical model for service life prediction to optimize concrete mixture

- reduced number of structural joints

- increased thickness of concrete cover of $10 \mathrm{~cm}$ for arch foundation and $5 \mathrm{~cm}$ for other elements

- better detailing, in comparison to older RC bridges

- installation of permanent structural health monitoring systems.

However, after nine years of maritime condition exposure, signs of chloride-induced corrosion were detected on the bridge during the first visual inspection in 2006 [40, 41]. Damage caused by chloride-induced corrosion has propagated significantly in next few years [27, 42-44] and the bridge is repaired in 2018 . Surface protection of structural elements involves corrosion inhibiting impregnation, structural repair mortar and protective coating, while at the most exposed and deteriorated elements high strength steel fibre reinforced concrete is applied and concrete cover depth is increased $[27,44]$. The upper part of the pier P2 foundation (mark: MB1), exposed to the airborne chlorides, was not included in repair in 2018; hence, it is used as a measuring location in the framework of this research (Figure 3).

\subsection{Pag Bridge}

Pag Bridge provides fixed road connection between the island of Pag and Croatian mainland across Ljubačka Vrata sea strait. Overall concrete structure was completed in 1968 employing at that time innovative large-span RC arch cantilever construction method [45]. The bridge is set in extremely aggressive maritime environment with high winds frequently splashing and spraying concrete members with sea water and airborne salt [8]. Additionally, the bridge has sustained direct missile hits during the Homeland war in the 1990s. The arch was strengthened and protected by an additional reinforced mortar layer and coating in 1991, while the thorough reconstruction was carried out in 1999, when the concrete superstructure was completely removed and replaced with the steel structure, the spandrel columns were jacketed with concrete and steel, and the arch coating was renewed [46]. The latest inspection and testing of concrete members of the Pag Bridge was carried out in 2015 [47] and followed by repair design in 2017 [48], which included six different repair techniques depending on damage assessment of structural members. For the most affected structural members repair envisaged the complete replacement of concrete cover with steel fibre reinforced concrete
C60/75 of increased depth as well as applying reinforcement protective coat and corrosion migration inhibitors with polymercement and polymer surface coating.

The measuring locations in the framework of this research are selected at the top surface of the arch, close to the arch abutment on the Pag island (mark: PB1 and PB2, Figure 3).

\subsection{Bridge of Youth}

Out of the three bridges in Zagreb chosen for this project, Bridge of Youth is the oldest one, built in 1974 . Bridge is $1188 \mathrm{~m}$ long, divided in three dilatations. Main bridge (central dilatation) is a composite structure, while north and south viaducts (side dilatations) comprise prestressed ribbed superstructure [49]. During the last visual inspection it was determined that most of the bridge is structurally and functionally compromised [50]. Signs of reinforcement corrosion are present on all the structural elements as a result of the following factors: no waterproofing exists on the RC deck exposed to the de-icing salts; improper functioning of the bridge drainage system, especially inside steel jackets of the concrete columns; bridge components such as expansion joints and bearings are severely damaged; poor quality and insufficient thickness of concrete cover. The eastern part of the south approaching viaduct was repaired in 2010, while rehabilitation of the western half of the south viaduct is planned in the near future. Measuring locations for this bridge include (Figure 3): bottom of the west rib girder on the south west approaching viaduct (marks: BY1, BY2) and north abutment wall of the north approaching viaducts (marks: BY3, BY4).

\subsection{Adriatic Bridge}

Adriatic bridge was built in 1981 and was the first contemporary prestressed concrete bridge in the Croatian capital. It consists of the main bridge (central dilatation) with seven spans and north and south approaching viaducts with one and four spans, respectively. Most of the superstructure comprises prefabricated girders 39 m long, a concrete deck and cross girders. The largest span above the river consists of $39 \mathrm{~m}$ long prefabricated girders and $12 \mathrm{~m}$ long pier cantilevers comprising box cross sections [49]. Various damage and deficiencies were noted during the last main inspection: threshold value of chlorides in concrete on the reinforcement level, concrete cracking and delamination due to reinforcement corrosion on main girders, columns, abutments; damaged or deteriorated bridge components. It was concluded that the bridge bearing capacity is reduced [51].

Measuring locations for this bridge include (Figure 3): column (mark: AB1), abutment wall (mark: $A B 2$ ) and wing (mark: $A B 3$ ), main prestressed concrete girder (mark: $A B 4-A B 6)$ and bottom plate (mark: AB7).

\subsection{Homeland bridge}

Homeland bridge built in 2006 is the newest Sava river crossing in Zagreb. The superstructure is extradosed prestressed box girder. 
Eight pairs of external tendons were used for each of the four deviators [49]. Certain problems were recorded during construction including concrete failing compressive test checks, cracks in the concrete after formwork removal, and additional prestressing of the box girder was required as a rehabilitation measure during construction. Additional repair work was done in 2012 due to the inadequate drainage solution around the cable stay anchors, which caused leak around the anchors inside the box girder [52]. New waterproofing and concrete layer for drainage slope was provided, but same problem persists even today. The conclusion of the last visual inspection is that the structure was overall in a good condition, except for some minor cracking in concrete around the anchor beams and cable stay deviators. However, no visible signs of reinforcement corrosion were detected.

Measuring locations include elements where concrete cracking is detected: internal face of the north east deviator (mark: HB1) and two locations on anchor frame inside the box girder (mark: HB2, HB3).

\section{6. Žeinci Bridge}

Žeinci Bridge is an RC tied arch bridge built in 1913, by far the oldest among the structures considered. Set in continental climate, it carries county road with imposed limits on vehicle weight up to 8 tonnes and speed up to $10 \mathrm{~km} / \mathrm{h}$.

The data on the bridge design, construction and maintenance is extremely limited, thus even the basic geometry is determined on site. The superstructure comprising of two RC longitudinal and seventeen cross girders joined by slab above is laterally suspended from two arch ribs by eight concrete hangers on each side. Superstructure underside reveals large portions of exposed corroded reinforcement.

Hanger 3 (from the west) on the southern bridge edge was selected as the measuring location (mark: ŽB1).

\section{Non-destructive testing on concrete bridges}

It is important to detect reinforcement corrosion, but also other damage in concrete, at an early stage in order to develop optimal maintenance plan resulting in reduction of cost and complexity of rehabilitation work and better control of structure deterioration progression. Available non-destructive testing (NDT) for evaluation of concrete structure durability and mechanical parameters includes following methods: acoustic (mechanical: chain drag, impact echo; and ultrasonic: ultrasonic pulse velocity, acoustic emission), electro-magnetic (ground penetrating radar), electro-chemical (half-cell potential, electrical resistivity, polarization resistance, galvanostatic pulse method, electrochemical noise), thermal (infrared thermography) and digital imaging (3D optical evaluation, viewer camera remote, digital image correlation) [39, 53-58]. In contrast to the destructive testing methods, NDT methods can be applied several times during the structure service life on greater number of structural elements and on larger surfaces in order to detect the locations with defects, rank damage levels and quantify measured properties. However, each NDT technique depends on numerous parameters (e.g. concrete mixture, material inhomogeneity, water content, etc) and results of bridge condition assessment using NDT are susceptible to environment condition, human error influence and data interpretation [56, 59]. In order to achieve better objectivity of results, it is recommended to combine several NDT methods during the structure condition assessment, especially those that do not depend on the same parameters [59]. Damage and deficiencies of a structure, detected by NDT, can be additionally assessed by semi-destructive and destructive testing, especially if there is a need for increased maintenance to slow down and localize structural deterioration.

The first objective of this research is validation of the proposed methodology, where visual inspections are combined with the simple NDT methods in order to detect damage earlier and/ or to assess structure condition more precisely in comparison with the cases when visual inspection is performed without NDT. After obtaining, analysing and interpreting NDT results, conclusions are compared with the results of the independently conducted additional tests, e.g. determination of chloride content in concrete and carbonatization depth, removal of concrete cover for visual inspection of reinforcement condition. The second goal is data collection from existing structures in real environmental conditions as input parameters for numerical models to predict further degradation and remaining service life of structures based on more relevant, directly measured data.

\subsection{Selected NDT methods}

In the framework of this research, NDT methods are selected based on their availability among bridge inspectors. Namely, cost effective and time efficient NDT methods can be more easily implemented as a standard component of the main visual inspection in order to assure more reliable bridge condition assessment. Moreover, measured parameters can be used for calibration of numerical models and simulations of structure deterioration during its remaining service life [15, 26, 27]. Depending on construction time and quality, executed concrete cover thickness can differ a lot from the design value required by the current codes [60]. Since construction quality, executed cover thickness and concrete damage have significant impact on a structure durability [61], survey by cover meter, determination of concrete uniformity, detection and measurements of concrete damage and cracks are provided by different methods described in the following subchapters.

Electro-chemical methods are the most suitable NDT methods to evaluate reinforcement corrosion in a concrete structure. Among them, measurements of half-cell potential and surface electrical resistivity of concrete are selected, since they provide evaluation of corrosion probability with acceptable accuracy (Table 3) [53, 62, 63]. Their results can be implemented in the numerical models for service life prediction and required devices are more affordable in engineering practice than devices for measurements of current density and polarization resistance [26]. 

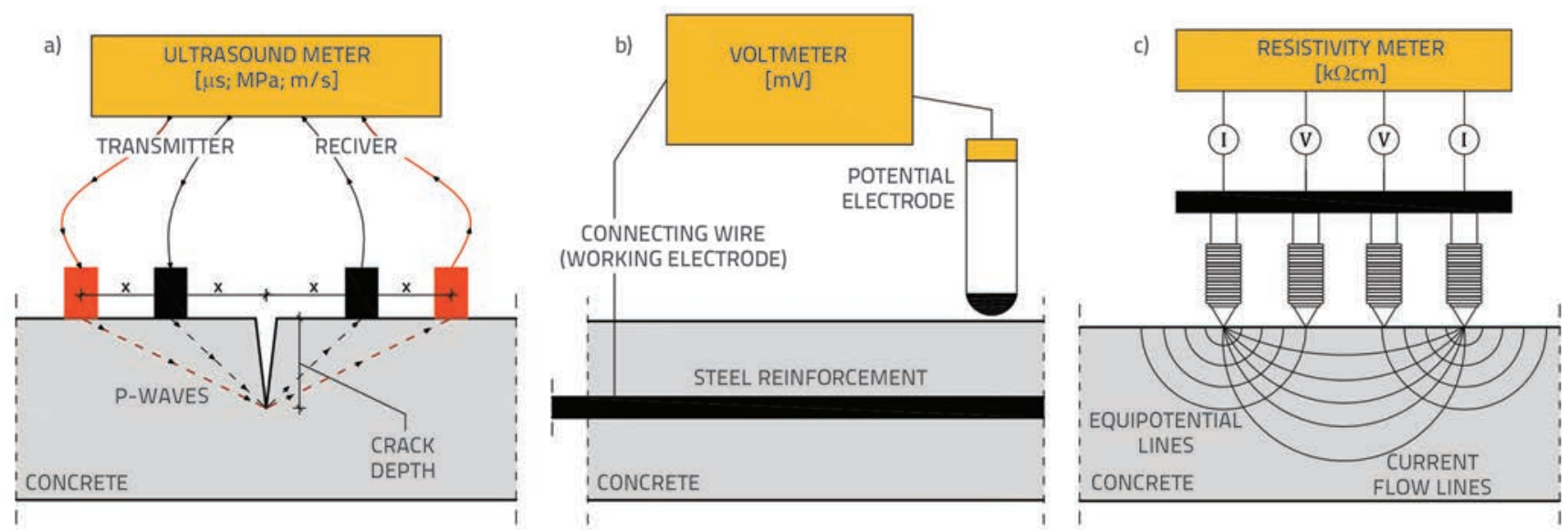

Figure 4. Graphical representation of some selected NDT methods: a) Ultrasound crack depth measurement, b) Half-cell potential measurement c) electrical resistivity Wenner probe principle (reproduced and modified from [53])

The activities carried out on the bridges include: rebar detection, measurements of rebar diameter and concrete cover, crack detection, determination of crack geometry and crack cause identification, estimation of strength and dynamic elastic modulus of concrete, measurements of surface electrical resistivity and half-cell potential. The principles of ultrasound crack depth measurement, half-cell potential measurement and electrical resistivity Wenner probe measurement are illustrated in Figure 4.

Table 3. Probability of active corrosion [53, 62, 63]

\begin{tabular}{|c|c|c|c|c|}
\hline Corrosion activity & High & Moderate & Low & Negligible \\
\hline $\begin{array}{c}\text { Half-cell potential } \\
{[\mathrm{mV}]}\end{array}$ \\
$\begin{array}{c}\text { (Cu/CuSO } \mathrm{S}_{4} \text { reference } \\
\text { electrode) }\end{array}$ & $<-350$ & -200 to -350 & $>-200$ & - \\
\hline $\begin{array}{c}\text { Electrical resistivity } \\
{[\mathrm{k} \Omega \mathrm{cm}]}\end{array}$ & $<10$ & 10 to 50 & 50 to 100 & $>100$ \\
\hline
\end{tabular}

\subsubsection{Cover meter}

Within this research, a cover meter is used during an on site bridge testing for two applications [64]:

- to determine the location of reinforcement as a preliminary test to some other form of testing in which reinforcement should be avoided or its nature taken into account (ultrasonic pulse velocity measurement and measurement of the electrical resistivity of concrete in this case)

- investigation of concrete members for which records are not available or need to be checked, including on site determination of concrete cover depth and bar sizes.

The instrument uses electromagnetic pulse induction technology: coils in the probe are periodically charged by current pulses, thus, generating a magnetic field and, as eddy currents are produced on the surface of any electrically conductive material in magnetic field, magnetic field in the opposite direction is induced, resulting in the change in voltage which is utilized for the measurement [65].

The used instrument has measuring accuracy that complies with BS 1881: Part 204 [64] and determination of the rebar diameter is limited to a maximum cover of about $63 \mathrm{~mm}$. Measured values require correction if there are multiple reinforcement layers, overlapping areas or welded mesh. Determined values of rebar diameters are validated by reviewing the bridge design documentation, delamination survey findings and/or measurement of the diameter of exposed rebars in vicinity of the measuring location, while for some measuring locations testing with a ground penetrating radar is also conducted.

\subsubsection{Optical microscope technique}

Optical high-quality microscope is used for measuring crack width in concrete. Instrument is placed with the lighted scope centred on the crack and focusing of the concrete surface is done by turning the knob. An eyepiece scale is then turned until it aligns perpendicular to the crack which allows for the crack width to be read. Using a phone camera, a photograph of the crack can be taken through the eyepiece for more accurate reading value (Figure 5).

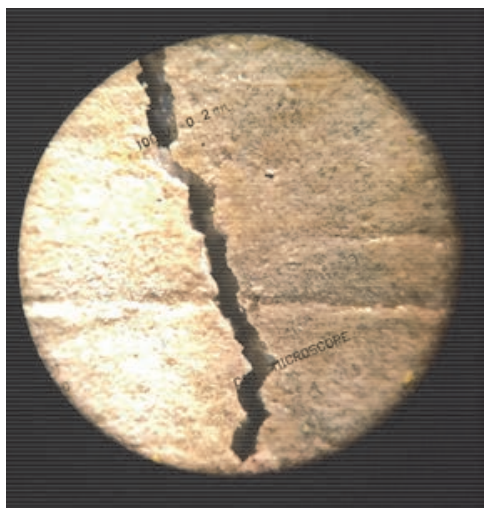

Figure 5. Measuring of crack width by optical microscope on the Homeland Bridge (HB2) 
Table 4. Typical orders of magnitude for the half-cell potential of steel in concrete measured by a $\mathrm{Cu} / \mathrm{CuSO}_{4}$ reference electrode [74]

\begin{tabular}{|c|c|c|}
\hline \multirow{2}{*}{ Concrete condition } & Half-cell potential [mV] \\
\cline { 2 - 3 } & Minimum value & Maximum value \\
\hline Water saturated concrete without $\mathrm{O}_{2}$ & -1000 & -900 \\
\hline Wet, chloride contaminated concrete & -600 & -400 \\
\hline Humid, chloride free concrete & -200 & +100 \\
\hline Humid, carbonated concrete & -400 & +100 \\
\hline Dry, carbonated/non-carbonated concrete & 0 & +200 \\
\hline
\end{tabular}

\subsubsection{Schmidt hammer}

Schmidt hammer is used to assess the uniformity of concrete strength and determine the potential locations of lower quality [66-69]. The device measures the velocities of impact, $v_{0^{\prime}}$ and of the rebound, $v_{R^{\prime}}$ immediately before and after the impact, giving the basic parameter - rebound value, $Q$ :

$Q=100 \cdot \sqrt{\frac{E_{R}}{E_{0}}}=100 \cdot \sqrt{\frac{\frac{m \cdot v_{R}^{2}}{2}}{\frac{m \cdot v_{0}^{2}}{2}}}=\frac{v_{R}}{v_{0}}$

where $m$ is the mass of hammer, $E_{o}$ and $E_{R}$ are kinetic energy of the needle impact just before and after the impact.

For the pier foundation of the Maslenica Bridge, a correlation function is found between the rebound values, $Q$, and the laboratory tested compressive strength of four concrete core samples, taken from the same location, to calculate the characteristic strength of concrete, $f_{\mathrm{ck}}\left[\mathrm{N} / \mathrm{mm}^{2}\right]$, considering the specific concrete mix and aggregate structure $[66,67]$ :

$f_{\mathrm{ck}}=0.000153 Q^{3}-0.021193 Q^{2}+1.739453 Q+0.000235$

where $\mathrm{Q}$ is the measured rebound value.

The lower $10^{\text {th }}$ percentile curve, which means that $90 \%$ of the samples lie above the curve and only $10 \%$ below, is used for the other measuring locations, where defining the correlation function was not possible due to the insufficient number of laboratorydetermined compressive strength of concrete samples taken from the same measuring location. For these cases, measurements are taken to qualitatively evaluate concrete uniformity and strength and to indicate possible areas of low quality.

\subsubsection{Ultrasonic pulse velocity}

An ultrasound instrument is used for determination of the homogeneity of concrete, presence of voids and cracks, quality of concrete, crack depth and Young module, by sending ultrasonic waves and measuring the velocity of sound propagation inside the material [70]. Due to the nature of the field testing, the position of the $54 \mathrm{kHz}$ transducers is always put for indirect (surface) transmission. Indirect placement of the transducers, symmetrical to the crack axis, allows calculation of the crack depth, $c_{d^{\prime}}$ assuming that the crack is perpendicular to element surface (Figure 4a) [70]:

$c_{d}=x \cdot \sqrt{\frac{4 T_{1}^{2}-T_{2}^{2}}{T_{2}^{2}-T_{1}^{2}}}$

where $x[\mathrm{~mm}]$ is a distance between the transducer and the crack axis, while $T_{1}$ and $T_{2}$ are the measured transit times across the crack for two different arrangements of the transducers (Figure 4a).

This is a recommended method for ultrasound crack measurements given in HRN EN 12504-4:2004 [71], and if the assumptions are met most of the results are within $15 \%$ of the actual depths [72].

\subsubsection{Half-cell potential}

Open circuit potential measurement is one of the most widely used methods for rebar corrosion assessment on existing reinforced concrete structures (Figure 4 b) [73]. The most commonly applied standard for this method, ASTM C876-09 [62], describes standard test method for corrosion potentials of uncoated reinforcing steel in concrete and evaluation of results (Table 3 ). The standard specifies that the method is limited to the uncoated reinforcing steel and by electrical circuitry, and highlights that the results obtained using this test method shall not be considered as a means for estimating the structural properties of the steel or of the reinforced concrete member. It is often necessary to use other data such as chloride contents, depth of carbonation, delamination survey findings, rate of corrosion results, and environmental exposure conditions, in addition to the corrosion potential measurements, to formulate conclusions concerning corrosion activity of embedded steel and its probable effect on the service life of a structure. The main influences on the half-cell potentials are: moisture, concrete cover thickness, electrical resistivity of the concrete, temperature and oxygen content at the reinforcement. When preparing the electrode, it is important to ensure:

- that the solution used to fill the electrode is saturated,

- that the electrode is filled as completely as possible with minimum of air in the compartment so that the solution is in contact with the wooden plug even when measuring in an upwards direction. 

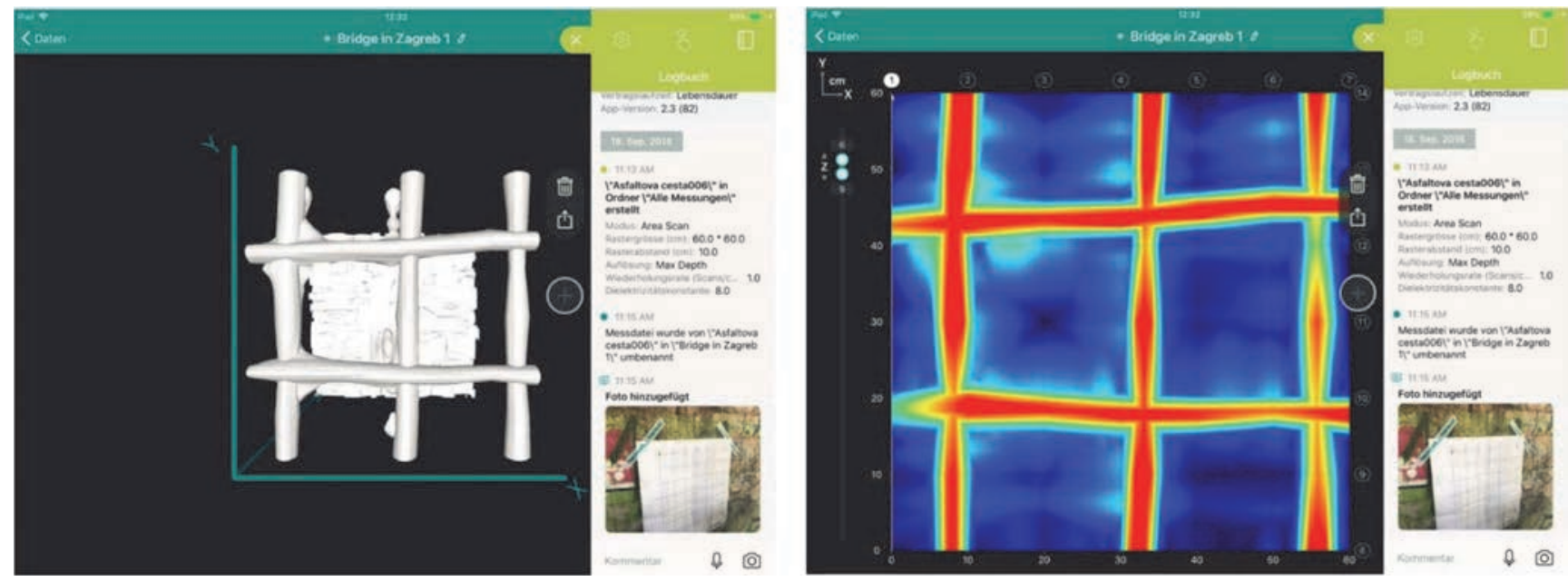

Figure 6. GPR scan on BY3: 3D view (left) and time slice view (right)

It is recommended to mark out a grid on the surface. Coarser grids are recommended for the first estimate and finer grid for the suspect areas. The potential field measurement even with a coarse grid delivers good results for chloride-induced corrosion. Corrosion due to carbonation is typified by the development of smaller macro-elements and is only possible to determine by using a very fine grid if at all.

Typical orders of magnitude (for information only) for the halfcell potential of steel in concrete measured by a $\mathrm{Cu} / \mathrm{CuSO}_{4}$ reference electrode according to the RILEM TC 154-EMC [74] are given in Table 4, while the most commonly used criteria according to the ASTM C 876 are given in Table 3.

\subsubsection{Electrical resistivity of concrete}

Surface electrical resistivity of concrete is one of the key durability performance indicators for evaluation of reinforcement corrosion in concrete. It provides additional information on current material and structure condition, but also enables to predict remaining service life of structures [75-79]. The device used for the measurement is based on the Wenner probe technique with alpha configuration, where four electrodes are in contact with the concrete surface (Figure 4c). The small current $/(A)$ is passed between the two outer probes, while potential difference $\Delta V(V)$ between two inner probes is measured and the electrical resistivity $\rho(\Omega \mathrm{m})$ is obtained by:

$\rho=2 \cdot \pi \cdot a \cdot \frac{\Delta V}{l}$

where $a=0.05 \mathrm{~m}$ is the distance between the two probes. Most important factor for reliable measurement is a good connection between the concrete surface and the electrodes. Thus, before the measurements the concrete surface should be smooth and cleaned of any coatings and dirt. Finally, as electrical current is transferred through the ions in the pore liquid, surface has to be wet for the successful measurements [80, 81]. During the measurements, the Wenner probe is oriented diagonally

to the rebar mesh and 6 to 12 measurements are provided in each field within the rebar mesh, depending on the size of the measurement location (higher number of individual tests in each field is provided if the total area of measurement location is smaller).

On-site resistivity measurements depend on many factors: concrete mixture, water content, porosity, chloride content, environment condition, temperature, etc. However, this simple NDT enables evaluation of current and future condition of reinforcement corrosion in initiation and propagation phase, because it is inversely proportional to chloride diffusivity and corrosion rate expressed as current density $[75,82]$. Hence, in the framework of this research the aim is to qualitatively assess the range of values that can be obtained on existing structures.

\subsubsection{Ground penetrating radar (GPR)}

Ground penetrating radar (GPR) is used to determine the location of rebars at the abutment wall of the Bridge of Youth (measuring location BY3). The instrument measuring principle is stepped-frequency continuous-wave GPR. Area scan showed the $1^{\text {st }}$ layer of rebars (Figure 6 ), while the wall depth and the $2^{\text {nd }}$ layer of rebars are not detected. This is probably due to the wall depth greater than the instrument measuring range $(70 \mathrm{~cm})$. The detected rebar layout corresponds quite well to the results obtained by cover meter, however, the time for preparation, testing and reporting is significantly reduced as real-time timeslice view is available.

\subsection{NDT methodology}

Preparation for bridge testing starts by obtaining and reviewing the documents on design and maintenance available for each bridge, summarised in Section 3. During preliminary visual inspection locations for testing are defined. NDT starts with cleaning of concrete surface and identification of reinforcement grid, then concrete cover and rebar diameter are measured. Crack width is 
measured by a ruler (crack width rod) and optical microscope, while crack depth and dynamic elastic modulus is estimated by ultrasonic pulse velocity device. Crack pattern and concrete cover delamination for the location with significantly damaged concrete due to reinforcement corrosion are recorded based on visual inspection and by sounding it (tapping it) with a hammer. Concrete strength is determined by Schmidt hammer. At the end of testing, half-cell potential and concrete resistivity are measured after wetting the concrete surface.

On some measuring locations, half-cell potential and concrete resistivity were not measured because of the presence of a surface coating on the concrete. Connection to the reinforcement, required for the half-cell potential measurements, could not be achieved on all measuring locations due to restrictions imposed by bridge owners (if the concrete cover is relatively deep and structure is in good condition or recently repaired). However, these limitations are overcome by adding sufficient number of total measuring locations on six bridges to achieve the research objectives. Locations where a measurement could not be provided are marked with "/" sign in Table 5.

\section{Results and discussion}

Summarized test results carried out on 18 measuring locations in total are presented in Table 5. Most measured locations (AB1-7, HB2-3, BY1-4, MB1) include at least one crack and the surrounding uncracked area. At deviator of Homeland Bridge (HB1) and hanger of Žeinci Bridge (ŽB 1) the concrete is evenly cracked, while on Pag Bridge (PB1-2) no crack is identified at the concrete surface. Causes of cracks are as follows: reinforcement corrosion (AB2-3, AB5, AB7, MB1), shrinkage (HB1), overloading (BY1-2), settlement (BY3), freezing-thawing process (ŽB1), local stress concentration due to prestressing cables (AB4, AB6) and cables anchoring (HB2-3). Due to the limitation of the paper length, measured values are presented in detail for three locations (MB1, BY4 and AB2). Surface plots of measured half-cell potential, electrical resistivity, rebound values and photo of the measuring location on the pier P2 foundation of the Maslenica Bridge (MB1) are shown in the Figure 7. Surface plots of half-cell potential and electrical resistivity measured on the abutment of the north approaching viaduct of values (right)
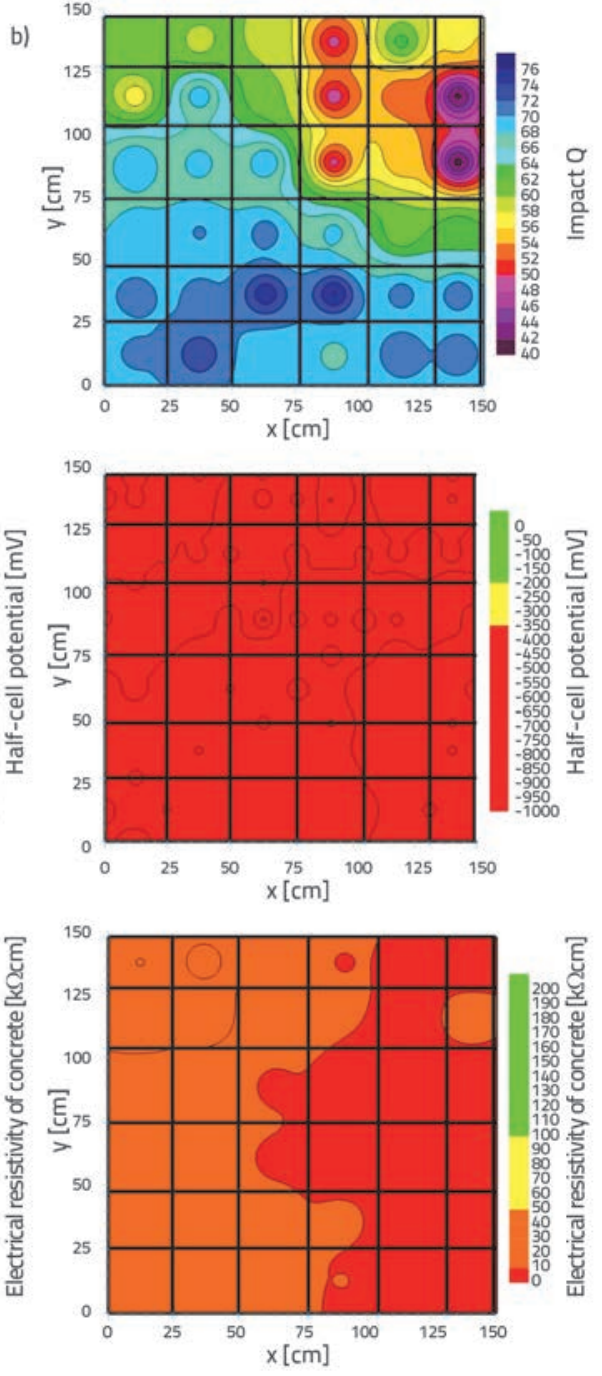

Figure 7. Measuring location on the pier P2 foundation of the Maslenica Bridge (MB1): a) photo, b) surface plot of measured rebound values; c) surface plot of measured half-cell potential with $20 \mathrm{mV}$ intervals in legend (left) and using ASTM standard C876-91 for boundary values (right) and d) surface plot of measured electrical resistivity with 2 $\mathrm{k} \Omega \mathrm{cm}$ intervals in legend (left) and using RILEM's recommendations for boundary

the Bridge of Youth (BY4) and on the southern abutment wall of the Adriatic Bridge (AB2) are presented in the Figures 8 and 9, respectively. Each surface plot for half-cell potential and electrical resistivity are presented in two ways:

- with small equipotential contour intervals in order to show gradients in measured results at each location

- using recommended boundaries as listed in Table 3: ASTM standard C876-91 for half-cell potential and Rilem recommendation for electrical resistivity; to present the condition in a more intuitive way.

Correlation between the half-cell potential and electrical resistivity are overviewed for all provided measurements in Figure 10. 
Table 5. Summarized results of provided NDT

\begin{tabular}{|c|c|c|c|c|c|c|c|c|c|c|c|c|}
\hline \multirow{2}{*}{$\begin{array}{c}\begin{array}{c}\text { Measuring } \\
\text { location }\end{array} \\
\begin{array}{c}\text { Structural } \\
\text { element }\end{array} \\
\end{array}$} & \multirow{2}{*}{ Values } & \multicolumn{2}{|c|}{$\begin{array}{l}\text { Transverse/ vertical } \\
\text { reinforcement }\end{array}$} & \multicolumn{2}{|c|}{$\begin{array}{l}\text { Longitudinal/ } \\
\text { horizontal } \\
\text { reinforcement }\end{array}$} & \multirow{2}{*}{\begin{tabular}{|c|}
$\begin{array}{c}\text { Half-cell } \\
\text { potential }\end{array}$ \\
{$[\mathrm{mV}]$}
\end{tabular}} & \multirow{2}{*}{\begin{tabular}{|c|}
$\begin{array}{c}\text { El. } \\
\text { resistivity }\end{array}$ \\
{$[\mathrm{k} \Omega \mathrm{cm}]$}
\end{tabular}} & \multicolumn{2}{|c|}{$\begin{array}{c}\text { Compressive strength } \\
{[\mathrm{MPa}]}\end{array}$} & \multicolumn{3}{|c|}{ Cracks } \\
\hline & & $\begin{array}{l}\text { Concrete } \\
\text { cover } \\
{[\mathrm{mm}]}\end{array}$ & $\begin{array}{l}\text { Diameter } \\
\text { [mm] }\end{array}$ & $\begin{array}{c}\text { Concrete } \\
\text { cover } \\
{[\mathrm{mm}]}\end{array}$ & $\begin{array}{c}\text { Diameter } \\
{[\mathrm{mm}]}\end{array}$ & & & \multicolumn{2}{|c|}{ Schmidt hammer test } & $\begin{array}{l}\text { Width } \\
{[\mathrm{mm}]}\end{array}$ & $\begin{array}{l}\text { Depth } \\
{[\mathrm{mm}]}\end{array}$ & $\begin{array}{l}\text { Lenght } \\
{[\mathrm{mm}]}\end{array}$ \\
\hline \multirow{4}{*}{$\begin{array}{c}\text { AB1 } \\
\text { Adriatic Bridge } \\
\text { Column S7 }\end{array}$} & $\min$ & \multirow{4}{*}{$\begin{array}{l}\text { Location } \\
\text { only }\end{array}$} & \multirow{4}{*}{$\begin{array}{l}\text { Location } \\
\text { only }\end{array}$} & \multirow{4}{*}{$\begin{array}{c}\text { Location } \\
\text { only }\end{array}$} & \multirow{4}{*}{$\begin{array}{c}\text { Location } \\
\text { only }\end{array}$} & \multirow{4}{*}{ Coating } & \multirow{4}{*}{ I } & Q-value & & & & \\
\hline & $\max$ & & & & & & & Q st. deviation & 1 & 025 & $75 ;$ & 2*300 mm \\
\hline & mean & & & & & & & $f_{c k}$ (sklerometer) & 1 & 0.23 & 126 & \\
\hline & st. dev. & & & & & & & $f_{c k}$ (drilled cores) & & & & \\
\hline & $\min$ & 34 & 18 & 52 & 28 & -434 & 6.3 & Q-value & $39.2-65.1$ & & & \\
\hline Adriatic Bridge & $\max$ & 56 & 27 & 52 & 28 & -126 & 39.1 & Q st. deviation & $3-9.7$ & 12 & $52(\mathrm{cal}$ & 1000 \\
\hline Abutment U4 & mean & 43.21 & 23.75 & 52 & 28 & -291.51 & 16.54 & $f_{c k}$ (sklerometer) & $18-63$ & 1.2 & $52(\mathrm{CL})$ & 1000 \\
\hline & st. dev. & 6.12 & & - & & 71.9 & 6.33 & $\mathrm{f}_{\mathrm{ck}}$ (drilled cores) & & & & \\
\hline AB3 & $\min$ & 32 & 11 & & & -390 & 20.3 & Q-value & $57-58.5$ & & & \\
\hline Adriatic Bridge & $\max$ & 47 & 17 & Location & Location & -73 & 44.4 & Q st. deviation & $4.3-5.4$ & $0.5-$ & 30 & $750 \mathrm{~mm}$ \\
\hline Abutment U4 & mean & 40.75 & 13.50 & only & only & -250.17 & 30.91 & $f_{c k}$ (sklerometer) & $44-46$ & 1.05 & 118 & $150 \mathrm{~mm}$ \\
\hline & st. dev. & 6.34 & & & & 87.0 & 6.58 & $\mathrm{f}_{\mathrm{ck}}$ (drilled cores) & & & & \\
\hline & $\min$ & 37 & 11 & & & & 156 & Q-value & 71.6 & & & \\
\hline $\begin{array}{c}\text { AB4 } \\
\text { Adriatic Bridge }\end{array}$ & $\max$ & 65 & 18 & Location & Location & Zaštitni & 1530 & Q st. deviation & 2.0 & $0.15-$ & 37; & 650 \\
\hline Girder N6 side & mean & 49.40 & 14 & only & only & sloj & 973.1 & $\mathrm{f}_{\mathrm{ck}}$ (sklerometer) & 86.0 & 0.20 & $\begin{array}{l}\text { U5; } \\
160\end{array}$ & 650 \\
\hline & st. dev. & 10.62 & & & & & 473.01 & $\mathrm{f}_{\mathrm{ck}}$ (drilled cores) & & & & \\
\hline & $\min$ & & & 33 & 18 & -215 & 16.1 & Q-value & 70.7 & & & \\
\hline $\begin{array}{c}\text { AB5 } \\
\text { Adriatic Bridge }\end{array}$ & $\max$ & Location & Location & 40 & 23 & -50 & 388 & Q st. deviation & 1.6 & 0.078 & 131 & $\begin{array}{l}300 \\
\text { (flange }\end{array}$ \\
\hline Girder N6 bottom & mean & only & only & 36.40 & 21.00 & -85.64 & 132.3 & $\mathrm{f}_{\mathrm{ck}}$ (sklerometer) & 82.5 & 0.078 & 131 & width) \\
\hline & st. dev. & & & 2.70 & & 30.88 & 117.36 & $\mathrm{f}_{\mathrm{ck}}$ (drilled cores) & & & & \\
\hline & $\min$ & & & & & & 548 & Q-value & 70.2 & & & \\
\hline $\begin{array}{c}\text { AB6 } \\
\text { Adriatic Bridge }\end{array}$ & $\max$ & Location & Location & Location & Location & No & 760 & Q st. deviation & 3.7 & 0.08 & $210 ;$ & 280 \\
\hline Girder N6 flange & mean & only & only & only & only & connection & 662.5 & $\mathrm{f}_{\mathrm{ck}}$ (sklerometer) & 80.5 & 0.08 & 203 & $\angle 80$ \\
\hline & st. dev. & & & & & & 64.08 & $f_{c k}$ (drilled cores) & & & & \\
\hline & $\min$ & & & & & & & Q-value & & & & \\
\hline Adriatic Bridge & $\max$ & Location & Location & Location & Location & No & 1 & Q st. deviation & 1 & 015 & 0.107 & 110 \\
\hline Girder N6 bottom & mean & only & only & only & only & connection & & $\mathrm{f}_{\mathrm{ck}}$ (sklerometer) & 1 & 0.15 & $9 ; 102$ & 170 \\
\hline & st. dev. & & & & & & & $\mathrm{f}_{\mathrm{ck}}$ (drilled cores) & & & & \\
\hline $\mathrm{HB} 1\left(15^{\circ} \mathrm{C}\right)$ & $\min$ & & & & & -65 & 49.3 & Q-value & $56-79$ & & & \\
\hline Domovinski most & $\max$ & Location & Location & Location & Location & -18.66 & 61.4 & Q st. deviation & $2.2-4.8$ & $0.05-$ & 25 & 25 \\
\hline Devijator S9 sa & mean & only & only & only & only & -47.69 & 55.62 & $\mathrm{f}_{\mathrm{ck}}$ (sklerometer) & $72-94$ & 0.06 & 25 & 25 \\
\hline & st. dev. & & & & & 18.70 & 4.08 & $f_{c k}$ (drilled cores) & & & & \\
\hline & $\min$ & & & & & -70.25 & 53.92 & Q-value & $56-79$ & & & \\
\hline $\begin{array}{c}\mathrm{HB} 1\left(20^{\circ} \mathrm{C}\right) \\
\text { Homeland Bridge }\end{array}$ & $\max$ & Location & Location & Location & Location & -18 & 99.17 & Q st. deviation & $2.2-4.8$ & $0.05-$ & 25 & 25 \\
\hline $\begin{array}{l}\text { Homeland Bridge } \\
\text { Deviator S9 side }\end{array}$ & mean & only & only & only & only & -44.67 & 75.18 & $\mathrm{f}_{\mathrm{ck}}$ (sklerometer) & $72-94$ & 0.06 & 25 & 25 \\
\hline & st. dev. & & & & & 15.96 & 12.39 & $\mathrm{f}_{\mathrm{ck}}$ (drilled cores) & & & & \\
\hline HB2 & $\min$ & 46 & 20 & 40 & 22 & & 172.5 & Q-value & & & & \\
\hline Homeland Bridge & $\max$ & 62 & 35 & 44 & 26 & No & 238 & Q st. deviation & 1 & 2 & 133; & 1320 \\
\hline Z5 anchor & mean & 51.40 & 27.80 & 41.50 & 24.00 & connection & 207.35 & $f_{c k}$ (sklerometer) & 1 & 0.2 & 116 & 1320 \\
\hline frame 1 & st. dev. & 5.68 & & 1.52 & & & 46.19 & $\mathrm{f}_{\mathrm{ck}}$ (drilled cores) & & & & \\
\hline & $\min$ & 46 & 20 & 40 & 22 & & 58.8 & Q-value & & & & \\
\hline Homeland Bridge & $\max$ & 62 & 35 & 44 & 26 & No & 80.8 & Q st. deviation & 1 & 0.2 & $125 ;$ & 1105 \\
\hline 25 anchor & mean & 51.40 & 27.80 & 41.50 & 24.00 & connection & 69.19 & $\mathrm{f}_{\mathrm{ck}}$ (sklerometer) & 1 & 0.2 & 32 & 1705 \\
\hline & st. dev. & 5.68 & & 1.52 & & & 7.38 & $\mathrm{f}_{c k}$ (drilled cores) & & & & \\
\hline & $\min$ & & & 20 & 19 & -400 & 6.9 & Q-value & $65.3-71.5$ & & & \\
\hline $\begin{array}{c}\text { BY1 } \\
\text { Bridge }\end{array}$ & $\max$ & Location & Location & 40 & 28 & -211 & 77.5 & Q st. deviation & $3.2-4.5$ & 0.45 & 46 & 400 \\
\hline $\begin{array}{l}\text { Bridge of Youth } \\
\text { Girder bottom } 1\end{array}$ & mean & only & only & 30.00 & 23.50 & -308.65 & 34.04 & $f_{c k}$ (sklerometer) & $63.5-85.5$ & 0.45 & 46 & 400 \\
\hline & st. dev. & & & 14.14 & & 46.56 & 16.92 & $\mathrm{f}_{\mathrm{ck}}$ (drilled cores) & & & & \\
\hline & $\min$ & 22 & 10 & 44 & 21 & -144 & 14.1 & Q-value & $72.5-73.8$ & & & \\
\hline BY2 & $\max$ & 28 & 22 & 44 & 21 & -53 & 40.6 & Q st. deviation & $2.3-2.8$ & & & \\
\hline $\begin{array}{l}\text { Bridge of Youth } \\
\text { Girder bottom } 2\end{array}$ & mean & 24.50 & 13.25 & 44.00 & 21.00 & -98.6 & 25.09 & $\mathrm{f}_{\mathrm{ck}}$ (sklerometer) & $90-95.5$ & 0.55 & 255 & 400 \\
\hline & st. dev. & 2.65 & & - & & 31.73 & 9.18 & $\mathrm{f}_{\mathrm{ck}}$ (drilled cores) & & & & \\
\hline
\end{tabular}


Table 5. Summarized results of provided NDT - continued

\begin{tabular}{|c|c|c|c|c|c|c|c|c|c|c|c|c|}
\hline \multirow{2}{*}{$\begin{array}{c}\begin{array}{c}\text { Measuring } \\
\text { location }\end{array} \\
\begin{array}{c}\text { Structural } \\
\text { element }\end{array} \\
\end{array}$} & \multirow{2}{*}{ Values } & \multicolumn{2}{|c|}{$\begin{array}{l}\text { Transverse/ vertical } \\
\text { reinforcement }\end{array}$} & \multicolumn{2}{|c|}{$\begin{array}{l}\text { Longitudinal/ } \\
\text { horizontal } \\
\text { reinforcement }\end{array}$} & \multirow{2}{*}{$\begin{array}{c}\begin{array}{c}\text { Half-cell } \\
\text { potential }\end{array} \\
{[\mathrm{mV}]}\end{array}$} & \multirow{2}{*}{$\begin{array}{c}\text { El. } \\
\text { resistivity } \\
{[\mathrm{k} \Omega \mathrm{cm}]}\end{array}$} & \multicolumn{2}{|c|}{$\begin{array}{c}\text { Compressive strength } \\
{[\mathrm{MPa}]}\end{array}$} & \multicolumn{3}{|c|}{ Cracks } \\
\hline & & $\begin{array}{l}\text { Concrete } \\
\text { cover } \\
{[\mathrm{mm}]}\end{array}$ & $\begin{array}{l}\text { Diameter } \\
{[\mathrm{mm}]}\end{array}$ & $\begin{array}{c}\text { Concrete } \\
\text { cover } \\
{[\mathrm{mm}]}\end{array}$ & $\begin{array}{c}\text { Diameter } \\
{[\mathrm{mm}]}\end{array}$ & & & \multicolumn{2}{|c|}{ Schmidt hammer test } & $\begin{array}{l}\text { Width } \\
{[\mathrm{mm}]}\end{array}$ & $\begin{array}{l}\text { Depth } \\
{[\mathrm{mm}]}\end{array}$ & $\begin{array}{l}\text { Lenght } \\
{[\mathrm{mm}]}\end{array}$ \\
\hline \multirow{4}{*}{$\begin{array}{c}\text { BY3 } \\
\text { Bridge of Youth } \\
\text { Abutment wall } 1\end{array}$} & $\min$ & \multirow{4}{*}{$\begin{array}{l}\text { Location } \\
\text { only }\end{array}$} & \multirow{4}{*}{$\begin{array}{l}\text { Location } \\
\text { only }\end{array}$} & 58 & 16 & -492 & 12.3 & Q-value & $58.1-69.2$ & \multirow{4}{*}{$3-3.5$} & \multirow{4}{*}{700} & \multirow{4}{*}{$\begin{array}{l}\text { height of } \\
\text { abutment, } \\
\text { cca. } 4500\end{array}$} \\
\hline & $\max$ & & & 59 & 17 & -331 & 111.5 & Q st. deviation & $2.8-7.1$ & & & \\
\hline & mean & & & 58.33 & 16.33 & -439.7 & 46.03 & $\mathrm{f}_{\mathrm{ck}}$ (sklerometer) & $49-76.5$ & & & \\
\hline & st. dev. & & & 0.58 & & 33.59 & 25.49 & $\mathrm{f}_{\mathrm{ck}}$ (drilled cores) & & & & \\
\hline \multirow{4}{*}{$\begin{array}{c}\text { BY4 } \\
\text { Bridge of Youth } \\
\text { Abutment wall } 2\end{array}$} & $\min$ & 40 & 18 & 37.5 & 13 & -549 & 14.2 & Q-value & $53.3-67.8$ & \multirow{4}{*}{ I } & \multirow{4}{*}{ I } & \multirow{4}{*}{ I } \\
\hline & $\max$ & 50 & 25 & 50 & 16 & -333 & 444 & Q st. deviation & $4.1-9$ & & & \\
\hline & mean & 44.86 & 20.36 & 41.73 & 14.00 & -441.44 & 68.13 & $\mathrm{f}_{\mathrm{ck}}$ (sklerometer) & $39.5-72$ & & & \\
\hline & st. dev. & 2.93 & & 3.65 & & 48.88 & 40.78 & $f_{c k}$ (drilled cores) & & & & \\
\hline \multirow{4}{*}{$\begin{array}{c}\text { ŽB1 } \\
\text { Žeinci Bridge } \\
\text { Hanger } 3\end{array}$} & $\min$ & 37 & 19 & \multirow{4}{*}{$\begin{array}{l}\text { Location } \\
\text { only }\end{array}$} & \multirow{4}{*}{$\begin{array}{l}\text { Location } \\
\text { only }\end{array}$} & -209 & 8.2 & Q-value & $66.5-67.4$ & \multirow{4}{*}{1.4} & \multirow{4}{*}{$\begin{array}{l}81 ; \\
104\end{array}$} & \multirow{4}{*}{300} \\
\hline & $\max$ & 40 & 30 & & & -55 & 40.31 & Q st. deviation & $3.5-6.1$ & & & \\
\hline & mean & 38.00 & 25.33 & & & -135.47 & 23.07 & $f_{c k}$ (sklerometer) & $68-70.5$ & & & \\
\hline & st. dev. & 1.73 & & & & 35.6 & 7.04 & $f_{c k}$ (drilled cores) & & & & \\
\hline \multirow{4}{*}{$\begin{array}{c}\text { MB1 } \\
\text { Maslenica Bridge } \\
\text { S2 Foundation }\end{array}$} & $\min$ & 40 & 19 & \multirow{4}{*}{$\begin{array}{l}\text { Location } \\
\text { only }\end{array}$} & \multirow{4}{*}{$\begin{array}{l}\text { Location } \\
\text { only }\end{array}$} & -657 & 2.10 & Q-value & $41.5-76.1$ & \multirow{2}{*}{$\begin{array}{c}0.08- \\
0.1\end{array}$} & 308 & 730 \\
\hline & $\max$ & 48 & 20 & & & -371 & 48.20 & Q st. deviation & $2.6-37$ & & & \\
\hline & mean & 44.14 & 19.43 & & & -521.76 & 11.33 & $\mathrm{f}_{\mathrm{ck}}$ (sklerometer) & $46.6-77.1$ & 0.2 & (cc) & 602 \\
\hline & st. dev. & 3.01 & 0.51 & & & 69.73 & 7.79 & $\mathrm{f}_{\mathrm{ck}}$ (drilled cores) & & & & \\
\hline \multirow{4}{*}{$\begin{array}{c}\text { PB1 } \\
\text { Pag Bridge } \\
\text { Arch } 1\end{array}$} & $\min$ & & & & & -331 & 6.90 & Q-value & $14-32.5$ & & & \\
\hline & $\max$ & $40 \mathrm{mn}$ & of shotcret & strengther & ed by & -70 & 77.8 & Q st. deviation & $8.4-12$ & & Delamin & ation \\
\hline & mean & reinforce & hent mesh & $4.2 / 100 x$ & $100 \mathrm{~mm}$ & -252.39 & 41.2 & $\mathrm{f}_{\mathrm{ck}}$ (sklerometer) & $14-32.5$ & & f shotcre & e layer \\
\hline & st. dev. & & & & & 52.46 & 24.72 & $f_{c k}$ (drilled cores) & & & & \\
\hline & $\min$ & & & & & -410 & 1.30 & Q-value & $41.5-48.4$ & & & \\
\hline $\begin{array}{c}\text { PB2 } \\
\text { Pag Rridgo }\end{array}$ & $\max$ & $40 \mathrm{mn}$ & ff shotcret & strengther & ed by & -203 & 41.4 & Q st. deviation & $11.2-12.4$ & & Delamin & \\
\hline Arch 2 & mean & reinforce & ent mesh & $4.27100 x$ & $100 \mathrm{~mm}$ & -295.89 & 14.2 & $\mathrm{f}_{\mathrm{ck}}$ (sklerometer) & $20.5-28.5$ & & f shotcre & e layer \\
\hline & st. dev. & & & & & 46.28 & 10.03 & $\mathrm{f}_{\mathrm{ck}}$ (drilled cores) & & & & \\
\hline
\end{tabular}

Brown spots and/or concrete cover delamination, as obvious signs of reinforcement corrosion, are observed only on six measuring locations (AB3, AB5, BY1, ŽB1, PB1, PB2), where measured values of half-cell potential and electrical resistivity indicate moderate to high risk of reinforcement corrosion (Table 5, Figure 10). Measured values of electrical resistivity bellow 15 $\mathrm{k} \Omega \mathrm{cm}$ and half-cell potential bellow $-400 \mathrm{mV}$ at four measuring locations ( $A B 2, B Y 3, B Y 4, M B 1)$ indicate high corrosion risk, despite the absence of visible signs of reinforcement corrosion (Table 5, Figure 10). These results confirm the statement that damage can be detected earlier by application of NDT rather than by visual inspection. Moreover, if a damage is already visible, measurements provided by NDT can determine the condition of the structure more precisely. For example, few cracks and partial colour change on the concrete surface are visually identified on the pier P2 foundation of the Maslenica Bridge (Figure 7.a). However, results of NDT (Figure 7.c and d) show extremely low electrical resistivity and very negative halfcell potential with high gradients. This combination of results, as can be seen also in Figure 10, indicates high chloride content in concrete and active corrosion with high corrosion rate (Figure 7). Determined chloride content in concrete at the reinforcement level above the threshold value on this element confirmed this conclusion [42]. For the same measuring location, rebound values are shown in Figure 7b, however, no correlation between the concrete strength and electrical resistivity or half-cell potential is found.

Similar results with high risk of chloride-induced reinforcement corrosion based on low values of electrical resistivity and half-cell potential are found at some locations on the arch of the Pag Bridge (Figure 10, Table 5). Results of comprehensive investigation works on the bridge confirms this conclusion and comprehensive repair is planned in the near future.

On the diagonally opposite side of Figure 10, the area with high values of electrical resistivity and half-cell potential indicates low or negligible risk of reinforcement corrosion, as was measured on the bottom of the girder on the Adriatic Bridge (AB5) and on the deviator of the Homeland Bridge (HB1).

On the bottom of the girder on the Adriatic Bridge (AB5), measured electrical resistivity is relatively low $(16-30 \mathrm{k} \Omega \mathrm{cm})$ in cracked region where brown spots from reinforcement corrosion are presented (Table 5, Figure 10). However, the resistivity of sound (un-cracked) concrete $80 \mathrm{~cm}$ away is approximately 20 times higher (Table 5, Figure 10). Relatively high values of electrical resistivity in uncracked concrete is consequences of low moisture in concrete, since the coating layer was applied on 
the surface. Although the brown spots from rust are visible on the cracked concrete surface, the values of halfcell potential are relatively high (0 to $-200 \mathrm{mV}$ ). This leads to conclusion that there is a possibility of reinforcement corrosion which progresses slowly, and it is limited to the cracked area only. Due to the high values of half-cell potential reinforcement corrosion is mainly induced by carbonatization.

High values and low gradients of halfcell potential on the deviator of the Homeland Bridge (HB1), the youngest bridge among the case studies, indicate passive reinforcement condition (Table 5, Figure 10). Nevertheless, multiple high-density cracks, caused by plastic shrinkage, in which water is retained long after the rainfall reduce electrical resistivity of concrete. This enables higher corrosion rates in the future following reinforcement depassivation. Measurements $\mathrm{HB} 1\left(20^{\circ} \mathrm{C}\right)$ and $\mathrm{HB} 1$ $\left(15^{\circ} \mathrm{C}\right)$ are provided in different weather conditions, confirming dependence of the electrical resistivity on the temperature (i.e. electrical resistance decreases with increasing temperature) (Table 5, Figure 10).

High values of half-cell potential (Table 5, Figure 10), measured on the hanger of the Žeinci Bridge (ŽB1) indicate low risk of reinforcement corrosion. However, due to long service life of the structure, slow progressive reinforcement corrosion caused by carbonation is possible, according to Table 4. According to the same table, values of half-cell potential indicate no presence of chlorides in the concrete. The facts that the structural element was covered by mortar layer until the NDT and that the Žeinci Bridge carries a road of lower importance, where significantly smaller amounts of salt are used, support this conclusion.

Most of the values measured on Bridge of Youth and Adriatic Bridge indicate moderate to high risk of corrosion according to the half-cell potential, while electrical resistivity indicates low to moderate risk of corrosion (Table 5, Figure 10). This is a consequence of concrete carbonation. Namely, due to the loss of the concentrated alkaline pore solution, carbonated concrete shows high resistivity [74]. Carbonation of concrete on the reinforcement level is confirmed

b)
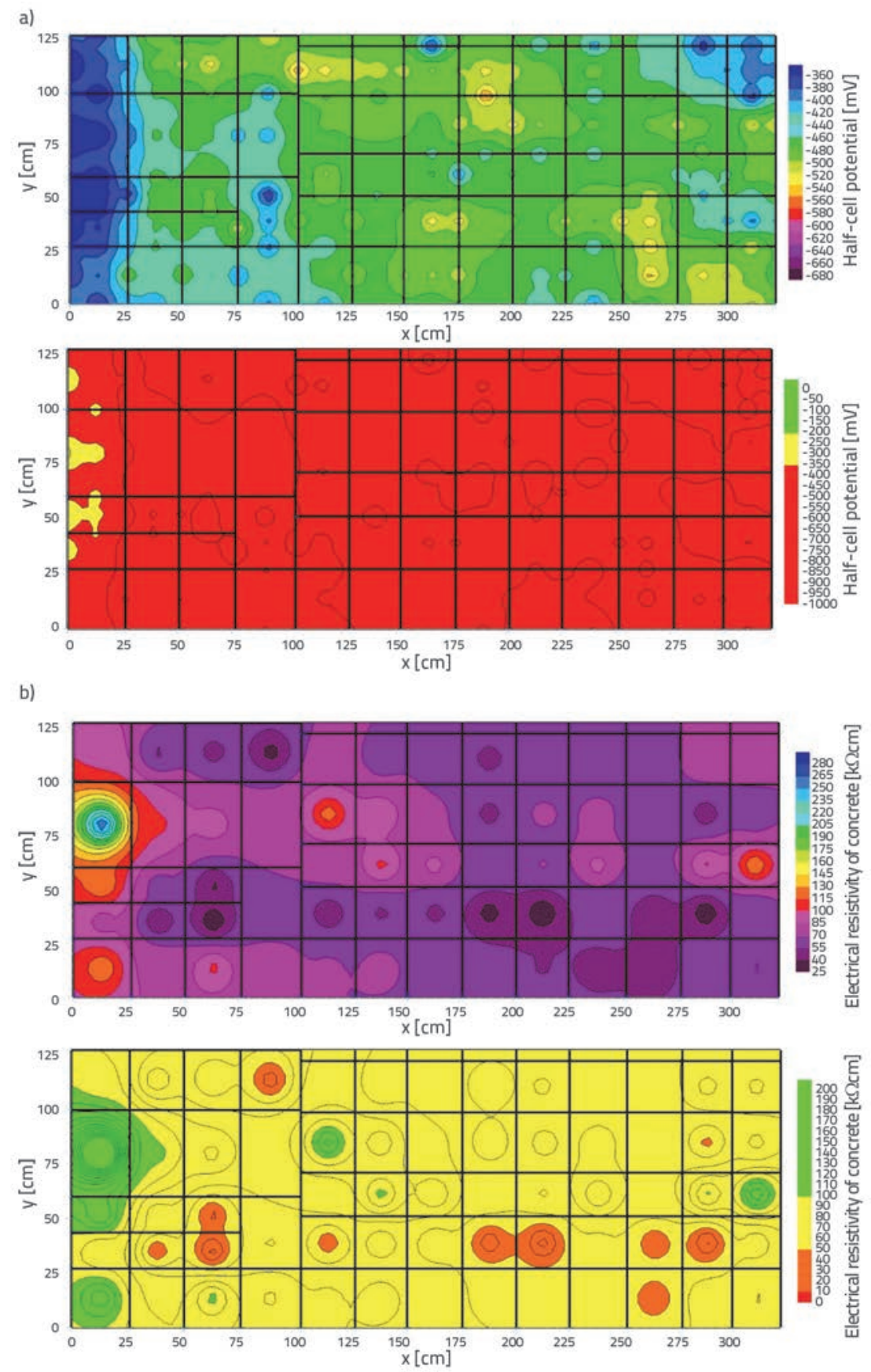

Figure 8. Measuring location on the abutment of the north viaduct of the Bridge of Youth (BY4): a) surface plot of measured half-cell potential with $20 \mathrm{mV}$ intervals in legend (above) and using ASTM standard C876-91 for boundary values (below) and b) surface plot of measured electrical resistivity with $10 \mathrm{k} \Omega \mathrm{cm}$ intervals in legend (above) and using RILEM's recommendations for boundary values (below)

by laboratory tests on samples taken from the measuring location of these two bridges [50,51], while active corrosion is confirmed by visual inspection after spalling of concrete cover on the same measuring location.

It should be noted that moisture content in concrete can change the value of half-cell potentia. However, the potential gradients and location of potential minima do not depend on the 

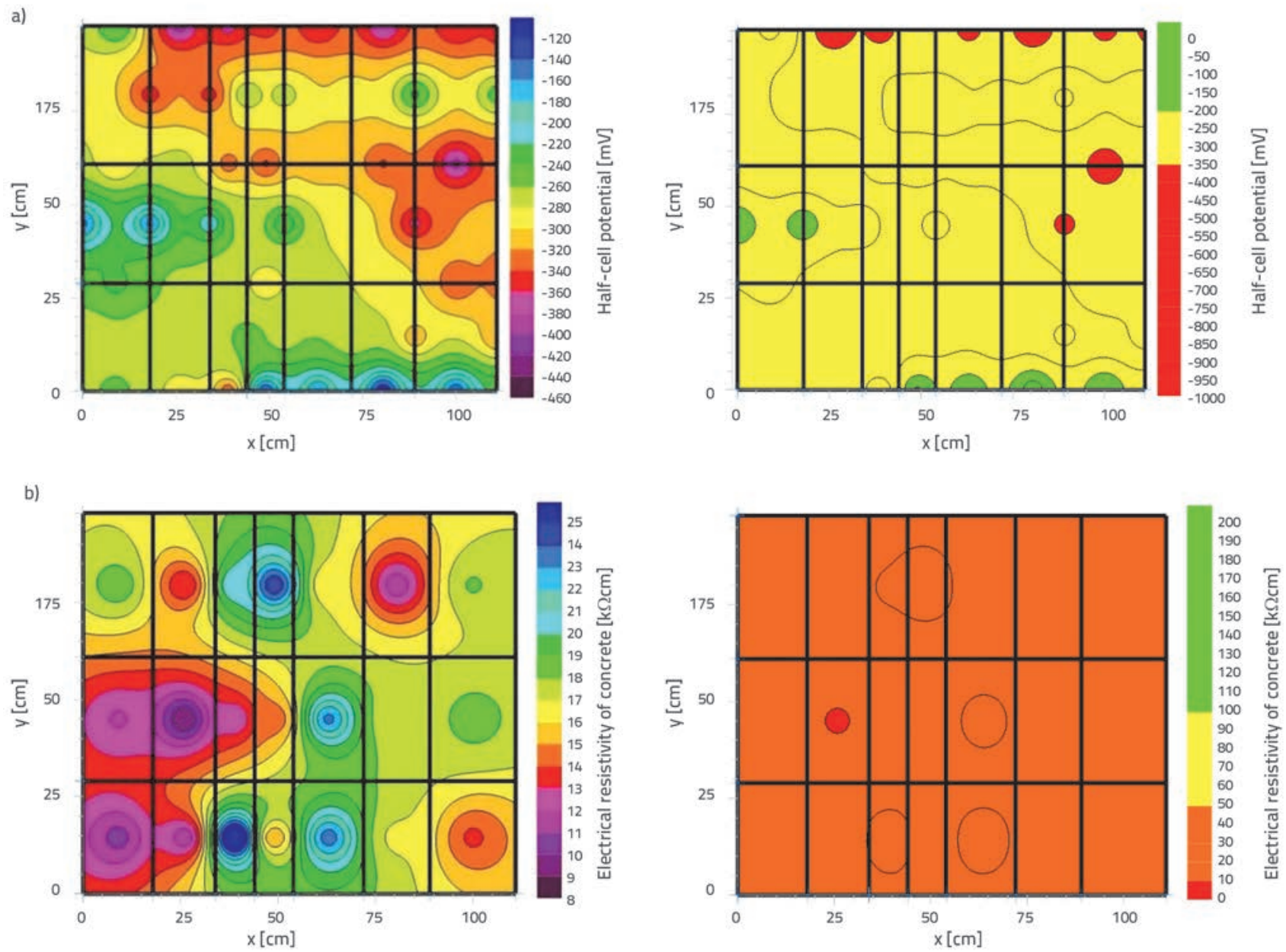

Figure 9. Measuring location on the southern U4 abutment wall of the Adriatic Bridge (AB2): a) surface plot of measured half-cell potential with $20 \mathrm{mV}$ intervals in legend (left) and using ASTM standard C876-91 for boundary values (right) and b) surface plot of measured electrical resistivity with $1 \mathrm{k} \Omega \mathrm{cm}$ intervals in legend (left) and using RILEM's recommendations for boundary values (right)

change of the water amount in concrete [74]. Hence, it is useful to present half-cell potential map for measured location (Figures 7c, 8a, 9a). The most negative values of half-cell potential indicate anode, corroding site, while more positive values indicate cathode, passive area. The most negative half-cell potential measured on the Maslenica Bridge (Figure 7c, left), with values up to $-657 \mathrm{mV}$, are marked with red and lilac colour; while the most positive half-cell potential, marked in blue, amounts up to $-371 \mathrm{mV}$. The most negative halfcell potential measured on the north abutment of the Bridge of Youth (Figure $8 \mathrm{a}$, above), with values up to $-594 \mathrm{mV}$, are marked with yellow colour; while the most positive half-cell potential, marked in blue, amounts up to $-333 \mathrm{mV}$. The

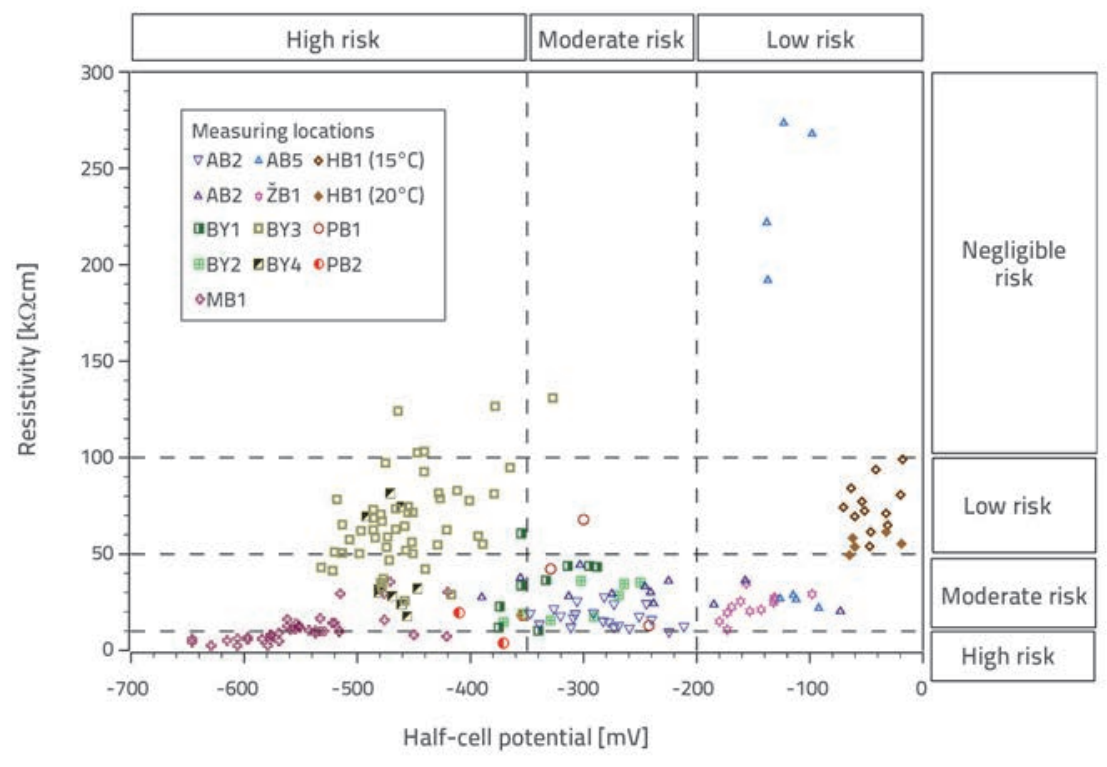

Figure 10. Correlation between half-cell potential and electrical resistivity for all measuring location 
most negative half-cell potential measured on the southern U4 abutment wall of the Adriatic Bridge (Figure 9a, left), with values up to $-434 \mathrm{mV}$, are marked with red and lilac colour; while the most positive half-cell potential, marked in blue, amounts up to $-126 \mathrm{mV}$. The biggest half-cell potential difference is measured on the Maslenica Bridge, and with the lowest measured electrical resistivity it can be concluded that among all measuring locations, the highest corrosion rate (current density) and the most progressive reinforcement corrosion appears on the pier P2 abutment of the Maslenica Bridge.

On the Maslenica Bridge (Figure 7), area with the lowest halfcell potential coincides with the area with the lowest electrical resistivity (lower right part in Figure $7 \mathrm{c}-\mathrm{d}$ ), which is typical for chloride-induced corrosion [74]. Partial overlapping of extreme values of the half-cell potential and the electrical resistivity is also observed on the abutment of the Bridge of Youth (Figure 8). However, on the abutment of the Adriatic Bridge, this phenomenon was not observed due to the influence of carbonation (Figure 9).

Values of half-cell potential and resistivity, measured on both abutments (BY4, AB2), indicate moderate risk of corrosion with lower corrosion rate comparing to the Maslenica Bridge. Causes of corrosion are chlorides, due to leakage of water with the de-icing salts through deteriorated expansion joint, and carbonation, whose influence is more pronounced on the Adriatic bridge.

One of the most important parameters related to reinforcement corrosion is concrete cover of sufficient quality and thickness. Measured concrete covers on analysed case studies (Table 5) are generally lower than the prescribed values according to the exposure classes in the current European Standard EN 206:2013 [83]. Measured concrete cover on abutments of Adriatic Bridge and Bridge of Youth (Table 5) vary from 30 to $59 \mathrm{~mm}$, while on some parts of the abutment wings rebars are exposed either due to the lack of concrete cover or it being only a few millimetres thick. Insufficient thickness and non-uniformity in execution is also determined on main girders of those bridges, with mean values of concrete cover thickness ranging from $24.50 \mathrm{~mm}$ to $49.40 \mathrm{~mm}$. Designed values for those older bridges vary from 40 to $50 \mathrm{~mm}$. Younger bridges, e.g. Maslenica Bridge and Homeland Bridge, are designed according to the more recent codes with greater awareness of durability issues and higher designed values of concrete cover. However, concrete cover for the pier foundation of the Maslenica Bridge has designed value of $50 \mathrm{~mm}$, while executed thickness varies from 40 to $48 \mathrm{~mm}$. Smaller concrete cover presents higher reinforcement corrosion risks. However, due to the differences among case studies in terms of types of structures, used materials, environmental exposure, condition, damage, age etc., more exact correlation with half-cell potential and electrical resistivity could not be established. Similar observation applies to concrete strength: in general, it can be concluded that the higher concrete strength by itself does not guarantee smaller corrosion risk and longer durability of a structure.

\subsection{Application of NDT results in service life prediction}

In order to implement sustainable bridge management, it is necessary to determine future deterioration and remaining service life of structures using numerical models. Although numerical models for service life prediction related to chlorideinduced reinforcement corrosion have been developed in recent four decades, there is still a huge space for improvement, such as $[7,29]$ : modelling the effect of damage (cracks) on transport and electrochemical processes in concrete; more accurate determination of the mutual dependence between corrosion, material, mechanical, structural and environmental parameters; modelling propagation phase of reinforcement corrosion including corrosion induced cracking of concrete; validation and improvement of existing models using data measured on existing bridges, etc.

Presented NDT results will be applied for the realistic simulation of processes before and after depassivation of reinforcement in concrete using the 3D chemo-hygro-thero-mechanical (CHTM) model $[82,84-90]$. The coupled 3D CHTM is one of the most comprehensive models for service life prediction. It includes transport processes in cracked and un-cracked concrete, wetting and drying cycles, calculation of current density and electrical potential distribution, transportation of rust into cracks and pores in concrete, corrosion-induced cracking of concrete cover, etc.

The parameters measured by the NDT (width, length and depth of crack, concrete cover, rebar diameter, concrete resistivity and gradient of half-cell potential) can serve as input parameters for calibration and verification of numerical models to simulate structure deterioration during remaining service life [7].

Damage and cracks in concrete caused during construction and/ or service life significantly accelerate reinforcement corrosion. Measured crack widths $(0.05-3.5 \mathrm{~mm})$ can significantly increase transport of chloride, water and oxygen in concrete comparing to the un-cracked concrete of the same quality.

Another time-varying parameter important for concrete durability is its electrical resistivity. Electrical resistivity depends on many parameters, e.g. porosity, water-to-cement ratio, aggregate, concrete curing, water and ions content in concrete, etc. Although several researches have been focused on determining influence of various parameters on electrical resistivity, development of numerical models of resistivity as a function of the most influencing parameters is still a challenging task. Also, electrical resistivity measurement technique is becoming a popular non-destructive method in the last two decades, due to its simplicity, rapidness, and cost during test conduction. Hence, measured electrical resistivity presents an important input parameter for service life prediction of a concrete structure.

Although measured half-cell potential cannot be directly compared with the calculated values of electric potential in numerical model, great gradients and very negative values measured on real structures provide useful information for 
anode and cathode configuration in the numerical models, whose surface and position should be assumed in advance due to computation issues.

\section{Conclusion}

An overview of bridge management in Croatia is given and causes of bridge deterioration are described. One of the main causes of premature deterioration of concrete bridges is reinforcement corrosion. Bridges exposed to the maritime environment or large amounts of de-icing salts during winter season, such as motorway bridges in the mountain regions, are especially vulnerable. Cracks and other damage in concrete additionally accelerate bridge deterioration.

The key activity in current bridge management is visual inspection. However, reinforcement corrosion can be detected by visual inspection only at the advanced stage, when structural repairs are required and chance for optimal maintenance of bridges is lost.

Hence, new approach of pro-active maintenance is proposed, where visual inspection is combined with the simple and efficient NDT methods. The proposed method is demonstrated on six representative case studies (Maslenica Bridge, Pag Bridge, Žeinci Bridge, Adriatic Bridge, Bridge of Youth and Homeland Bridge). Measurements performed on 18 locations in total are showing that all bridge elements, e.g. girders, deviators, hangers, abutments and piers, can be vulnerable to concrete cracking and reinforcement corrosion. Although each NDT has limitations in terms of measurement accuracy, use of NDTs increases the objectivity and precision of the visual inspection results and allows the detection of invisible defects, which is confirmed by the independent destructive testing in the presented case studies. On the other hand, if damage is already visible, NDT can more accurately determine the degree of deterioration.

Based on the conducted measurements, the highest corrosion rate and the fastest structure deterioration can be expected on the pier P2 foundation of Maslenica Bridge and on the arch of the Pag Bridge. Both bridges are exposed to the harsh maritime environment and active chlorideinduced corrosion is confirmed on these structures. The youngest Homeland Bridge is in the best condition among the case studies; however, repair of the observed cracks is recommended to ensure the durability and reduce the risk of corrosion in the future. Older bridges (Žeinci Bridge, Bridge of Youth and Adriatic Bridge) have moderate risk of reinforcement corrosion: although active reinforcement corrosion is present on measured locations, corrosion rate is lower than on Adriatic bridges due to the influence of concrete carbonation.

For more accurate determination of reinforcement corrosion progress in the future, numerical model for service life prediction are required. In the frame of this project [91], the recently developed 3D chemo-hygro-thermo mechanical model will be used for realistic simulation of corrosion processes before and after steel depassivation. Data from bridge testing will be used for improvement and verification of the numerical models. Finally, future condition of bridges during the remaining service life, predicted by the numerica models, can serve as an important basis for optimal bridge maintenance.

\section{Acknowledgements}

This research is carried out in the framework of the UKF project 04/17 "Influence of concrete damage on reinforcement corrosion - computer simulation and inservice performance of bridges (CODEbridges)" supported by the Unity through Knowledge Fund. The authors highly acknowledge the road authorities for bridge maintenance data and their support during research. Special gratitude goes to their associates in this project: Mladen Burić (Country roads of Krapina-Zagorje County), Stjepko Devald (Croatian Motorways), Sanjin-Velebit Pešut (Rijeka Zagreb Motorway), Danijel Tenžera (Croatian Roads) and Krunoslav Tepeš (City of Zagreb).

\section{REFERENCES}

[1] Tenžera, D., Puž, G., Radić, J.: Visual inspection in evaluation of bridge condition, Gradevinar, 64 (2012) 9, pp. 717-726.

[2] HRN EN 1990:2011 Eurocode: Basis of structural design National Annex (EN 1990:2002+A1:2005/AC:2010), HZN,2011.

[3] Radić, J., Kučer, A., Medak, M., Kalafatić, I.: Stanje nadvožnjaka nad starijim dionicama hrvatskih autocesta, Građevinar, 59 (2007) 6, pp. 495-504.

[4] Calvi, G. M., Moratti, M., O'Reilly, G. J., Scattarreggia, N., Malomo, D., Monteiro, R., Pinho, R.: Once upon a time in Italy: the tale of the Morandi bridge, Submitted to Structural Engineering International, 8664 (2018), http://dx.doi.org/10.1080/10168664.2018.155803 3.
[5] Madaj, A., Siekierski, W.: Determination of Defect Factors for a Road Bridge Made of Prestressed Concrete, Structural Engineering International, 27 (2017) 3, pp. 388-393, http://dx.doi. org/10.2749/101686617X14881932436735.

[6] Tanner, P., Hingorani, R., Thomas, J. L. B., Cid, D. S.: Learning from incidents during bridge erection, IABSE Madrid Symposium: Engineering for Progress, Nature and People, 102 (2014), pp. 1047-1054, http://dx.doi.org/10.2749/222137814814067275.

[7] Zerayohannes, G., Gebreyouhannes, E., Zekaria-Abdullahi, A.: Investigation of the Cause of Failure of the Omo River Bridge, Structural Engineering International, 27 (2017) 3, pp. 418-421, http://dx.doi.org/10.2749/101686617X14881937384729. 
[8] Radić, J., Šavor, Z., Puž, G.: Extreme wind and salt influence on adriatic bridges, Structural Engineering International: Journal of the International Association for Bridge and Structural Engineering (IABSE), 13 (2003) 4, pp. 242-245, http://dx.doi. org/10.2749/101686603777964487.

[9] Liu, Z., Guo, T., Pan, S., Liu, J.: Forensic Investigation on Cracking in Hanger-to-Girder Connections of Long-Span Suspension Bridges, Structural Engineering International, 27 (2017) 3, pp. 344-352, http://dx.doi.org/10.2749/101686617X14881937384963.

[10] Mandić Ivanković, A., Srbić, M., Franetović, M.: Performance of existing concrete arch bridges, in IABSE Conference - Structural Engineering: Providing Solutions to Global Challenges Geneva, Switzerland, 2016, http://dx.doi. org/10.2749/222137815818358268.

[11] Fargier Gabaldón, L.B.: Rehabilitation and Lessons Learned from the Collapse of Viaduct 1 Located on the CaracasLa-Guaira Highway in Venezuela, Structural Engineering International, 27 (2017) 3, pp. 380-387, http://dx.doi. org/10.2749/101686617X14881937385007.

[12] Hwang, Y.C., Kim, S.J., Kim, H.K.: Report of an unexpected vortex-induced vibration in an actual suspension bridge, IABSE Conference, Geneva 2015: Structural Engineering: Providing Solutions to Global Challenges - Report, pp. 23-26, 2015.

[13] Godart, B., Paris-est, U., Lacombe, J., Aubagnac, C.: Failures of external Tendons in Prestressed Concrete Bridges, Causes, Investigations, Remediation and Prevention, 2015.

[14] Kušter Marić, M., Radić, J., Ožbolt, J., Balabanić, G.: Analysis on Durability of Reinforced Concrete Bridges in Maritime Environment, Annual 2015 of the Croatian Academy of Engineering, pp. 57-78, 2016.

[15] Kušter Marić, M., Mandić Ivanković, A., Ožbolt, J.: Structural and climate performance indicators in service life prediction of concrete bridges in multi-hazard environment, in Life Cycle Analysis and Assessment in Civil Engineering: Towards an Integrated Vision: Proceedings of the Sixth International Symposium on Life-Cycle Civil Engineering (IALCCE 2018), pp. 1701-1707, Ghent, 2018.

[16] Rodriguez, J., Ortega, L.M., Casal, J.: Load Carrying Capacity of Concrete Structures With, Construction and Building Materials. 11 (1997) 4, pp. 239-248, http://dx.doi.org/10.1016/S09500618(97)00043-3.

[17] Du, Y.G., Clark, L.A., Chan, A.H.C.: Residual capacity of corroded reinforcing bars, Magazine of Concrete Research, 57 (2005) 3, pp. 135-147, http://dx.doi.org/10.1680/macr.57.3.135.60482.

[18] Chan,. H.C., Clark, L., Du, Y.G.: Effect of corrosion on ductility of reinforcing bars, Magazine of Concrete Research, 57 (2005) 7, pp. 407-419, http://dx.doi.org/10.1680/macr.2005.57.7.407.

[19] Cairns, J., Plizzari, G.A., Du, Y., Law, D.W., Franzoni, C.: Mechanical Properties of Corrosion-Damaged Reinforcement, 102 (2005), pp. 2005.

[20] fib: Bond of reinforcement in concrete-State of art report. Prepared by fib Task Group Bond Models. fib Bulletin 10. Structural consequences of corrosion in reinforced concrete structures. 2000.

[21] Tuutti, K.: Corrosion of steel in concrete: Tech. Report. Stockholm: Swedish Cement and Concrete Research Institute., 1982.

[22] Zandi Hanjari, K.: Structural Behaviour of Deteriorated Concrete Structures $\mathrm{PhD}$ thesis, Gothenburg, Sweden: Chalmers University of Technology - Department of Civil and Environmental Engineering - Division of Structural Engineering, 2010.
[23] Kurtis, K.E., Metita, K.A.: Critical review of deterioration of concrete due to corrosion of reinforcing steel, in Proceedings of $4^{\text {th }}$ CANMET/ACI Int. Conference, 1 (1978), SP 170, Sydne.

[24] Grandić, D., Bjegović, D., Radić, J.: Nosivost i uporabljivost armiranobetonskih konstrukcija oštećenih korozijom armature, Gradevinar, 52 (2000) 3, pp. 153-162.

[25] CEB: Structural consequences of corrosion in reinforced concrete structures, in Durable Concrete Structures CEB Bulletin, p. 183, 1992.

[26] Kušter Marić, M., Ožbolt, J., Mandié Ivanković, A., Bleiziffer, J., Srbić, M., Skokandić, D., Hrelja, G., Mujkanović, N.: QUALITY SPECIFICATION FOR CONCRETE BRIDGES VULNERABLE TO REINFORCEMENT CORROSION, in eBook of the $3^{\text {rd }}$ Workshop Meeting Cost Action TU1406, pp. 1-8, no. i, Wroclaw, 2018.

[27] Kušter Marić, M., Bleiziffer, J., Vlašić, A., Ožbolt, J., Mandić lvanković, A., Srbić, M., Skokandić, D., Hrelja Kovačević, G., Mujkanović, N., Devald, S., Tenžera, D., Tepeš, K., Burić, M., Lacković, L.: In-service performance of road concrete bridges - set up of case studies for novel pro-active maintenance methodology, in Proceedings of the 5th International Conference on Road and Rail Infrastructures CETRA 2018, pp. 139-145, Zagreb: Department of Transportation Faculty of Civil Engineering, 2018.

[28] Puž, G., Radić, J., Tenžera, D.: Predvidanje stanja mostova radi optimalizacije održavanja, GRADEVINAR, 65 (2013) 12, pp. 10791088.

[29] Alexander, M., Beushausen, H.: Durability, service life prediction, and modelling for reinforced concrete structures - review and critique, Cement and Concrete Research, 122 (2019), pp. 17-29, http://dx.doi.org/https://doi.org/10.1016/j. cemconres.2019.04.018.

[30] Šavor, Z., Šavor, M., Srbić, M.: Krk bridge from inception to today, in CONSTRUCTION OF ARCH BRIDGES, pp. 377-395, Zagreb, 2009.

[31] Bazant, Z.P.: Physical Model for Steel Corrosion in Concrete Sea Structures - Theory, Journal of the Structural Division, 105 (1979) June, pp. 1137-1153.

[32] Bazant, Z.P.: Physical Model for Steel Corrosion in Concrete Sea Structures - Application, Journal of the structural division, 105 (1979) June, pp. 1155-1166, 1979.

[33] Rosenberg, A., Hansson, C.M., Andrade, C.: Mechanism of corrosion of steel in concrete, Materials Science of Concrete, 1 (1989), pp. 285-313.

[34] Wang, H.L., Dai, J.G., Sun, X.Y., Zhang, X.L.: Characteristics of concrete cracks and their influence on chloride penetration, Construction and Building Materials, 107 (2016), pp. 216-225.

[35] Yup, S., Sung, B., Hwan, B.: Cement and Concrete Research Effect of crack width on chloride diffusion coef fi cients of concrete by steady-state migration tests, , Cement and Concrete Research, 41 (2011) 1, pp. 9-19.

[36] Djerbi, A., Bonnet, S., Khelidj, A., Baroghel-bouny, V.: Influence of traversing crack on chloride diffusion into concrete, Cement and Concrete Research. 38 (2008) 6, pp. 877-883.

[37] Park, S.S., Kwon, S.J., Jung, S.H.: Analysis technique for chloride penetration in cracked concrete using equivalent diffusion and permeation, Construction and Building Materials, 29 (2012), pp. 183-192.

[38] Bjegović, D., Serdar, M., Baričević, A., Rukavina, M.J.: Ocjena stanja betonskog obalnog zida izloženog djelovanju morske vode više od 30 godina, GRADEVINAR, 67 (2015) 12, pp. 1155-1164, http:// dx.doi.org/10.14256/JCE.1188.2014. 
[39] Alani, A.M., Aboutalebi, M., Kilic, G.: Integrated health assessment strategy using NDT for reinforced concrete bridges, NDT and E International, 61 2014), pp. 80-94, http://dx.doi.org/10.1016/j. ndteint.2013.10.001.

[40] Report on quality testing of concrete built-in Maslenica Bridge (Project: Durability of reinforced concrete structures in maritime environment - TABKIMO), Zagreb, 2007.

[41] Stipanović, I., Bjegović, D., Mikulić, D., Serdar, M.: Time dependent changes of durability properties of concrete from Maslenica Bridge at the Adriatic coast, in Integral Service Life Modelling of Concrete Structures, pp. 87-95, Bagneux, 2007.

[42] Maslenički most, Izvještaj s glavnog pregleda mosta, Institut IGH, d.d., Zagreb, 2011.

[43] Bleiziffer, J., Mavar, K., Ille, M., Škarić Palič, S., Dimić Vuković, S., Balagija, A.: CONDITION ASSESSMENT OF THE MASLENICA HIGHWAY BRIDGE, in SUSTAINABLE ARCH BRIDGES, pp. 309316, Zagreb, 2011.

[44] Sanacija i zaštita betonske konstrukcije Masleničkog mosta, projekt sanacije, Institut IGH, d.d, Zagreb, 2014.

[45] Marić, Z.: Pag Bridge, Ceste i mostovi, 34 (1988) 4, pp. 171-173.

[46] Šavor, Z.; Mujkanović, N.; Hrelja, G.; Bleiziffer, J.: Reconstruction of the Pag bridge, in Proceedings of the $1^{\text {st }}$ Chinese-Croatian Joint Colloquium on LONG ARCH BRIDGES, pp. 241-252, 2008.

[47] Paški most na državnoj cesti D106, Izvještaj o istražnim radovima na AB konstrukciji mosta, Institut IGH, d.d., Zagreb, 2016.

[48] Paški most na državnoj cesti D106, Projekt sanacije AB elemenata, Institut IGH d.d., Zagreb, 2017.

[49] Radić, J., Vlašić, A., Puž, G., Kolić, D.: Zagreb Bridges, in Proceedings of Gold Parliament of CSSE, pp. 213-220, Zagreb: CSSE Secon, 2003.

[50] Izvješće s glavnog šestogodišnjeg pregleda Mosta Mladosti, Institut IGH d.d., Zagreb, 2017.

[51] Izvješće s glavnog šestogodišnjeg pregleda Jadranskog mosta, Geoexpert-IGM d.o.o., Zagreb, 2017.

[52] Izvješće s glavnog šestogodišnjeg pregleda Domovinskog mosta, Ascon Institut d.o.o., Zagreb, 2017.

[53] Zaki, A., Chai, H.K., Aggelis, D.G., Alver, N.: Non-destructive evaluation for corrosion monitoring in concrete: A review and capability of acoustic emission technique, Sensors (Switzerland), 15 (2015) 8, pp. 19069-19101, http://dx.doi.org/10.3390/ s150819069.

[54] du Plooy, R., Villain, G., Palma Lopes, S., Ihamouten, A., Dérobert, X., Thauvin, B.: Electromagnetic non-destructive evaluation techniques for the monitoring of water and chloride ingress into concrete: a comparative study, Materials and Structures/ Materiaux et Constructions, 48 (2015) 1-2, pp. 369-386, http:// dx.doi.org/10.1617/s11527-013-0189-z.

[55] Garnier, V., Piwakowski, B., Abraham, O., Villain, G., Payan, C., Chaix, J.F.: Acoustic techniques for concrete evaluation: Improvements, comparisons and consistency, Construction and Building Materials, 43 (2013), pp. 598-613, http://dx.doi.org/10.1016/j. conbuildmat.2013.01.035.

[56] Omar, T., Nehdi, M.: Condition Assessment of Reinforced Concrete Bridges: Current Practice and Research Challenges, Infrastructures, 3 (2018) 3, pp. 36, http://dx.doi.org/10.3390/ infrastructures 3030036.

[57] Hoła, J., Schabowicz, K.: State-of-the-art non-destructive methods for diagnostic testing of building structures - anticipated development trends, Archives of Civil and Mechanical Engineering, 10 (2010) 3, pp. 5-18, http://dx.doi.org/10.1016/S16449665(12)60133-2.
[58] Sekulić, D., Bjegović, D., Mikulić, D.: Monitoring armaturnog čelika u betonu, Gradevinar, 52 (2000), pp. 577-586.

[59] Breysse, D., Klysz, G., Dérobert, X., Sirieix, C., Lataste, J.F.: How to combine several non-destructive techniques for a better assessment of concrete structures, Cement and Concrete Research, 38 (2008) 6, pp. 783-793, http://dx.doi.org/10.1016/j. cemconres.2008.01.016.

[60] Eurocode: Eurocode 2 - Design of concrete structures - Part 1-1: General rules and rules for buildings, vol. BS En 1992. Brussels: European Committee for Standardization CEN, 2004.

[61] Alexander, M.G., Ballim, Y., Stanish, K.: A framework for use of durability indexes in performance- based design and specifications for reinforced concrete structures, Materials and Structures, 41 (2008), pp. 921-936, http://dx.doi.org/10.1617/s11527-0079295-0.

[62] ASTM C876 - 91(1999) Standard Test Method for Half-Cell Potentials of Uncoated Reinforcing Steel in Concrete, American Society for Testing and Materials, 2008.

[63] Legat, A.: Monitoring of steel corrosion in concrete by electrode arrays and electrical resistance probes, Electrochimica Acta, 52 (2007) 27, SPEC. ISS., pp. 7590-7598, http://dx.doi.org/10.1016/j. electacta.2007.06.060.

[64] BS 1881-204: Testing Concrete - Part 204: Recommendations on the Use of Electromagnetic Covermeters, British Standards Institution (BSI), 2014.

[65] Profometer Operating Instructions, Proceq, Schwerzenbach, 2017.

[66] EN 13791:2007 Assessment of in-situ compressive strength in structures and pre-cast concrete components, 2007.

[67] Proceq, S.A.: Operating Instructions - Operating Instructions SilverSchmidt \& Hammerlink, Schwerzenbach, Switzerland, p. 30, 2017.

[68] Aydin, A.: ISRM Suggested Method for Determination of the Schmidt Hammer Rebound Hardness: Revised Version, Springer pp. 25-33, 2015.

[69] Hobbs, B., Tchoketch Kebir, M.: Non-destructive testing techniques for the forensic engineering investigation of reinforced concrete buildings, Forensic Science International, 167 (2007) 2-3. pp. 167-172.

[70] NDT James Instruments: V-C-400-V-Meter Mark IV - Operator's Manual, Chicago, p. 104, 2017.

[71] EN 12504-4:2004 Testing concrete -- Part 4: Determination of ultrasonic pulse velocity, 2004

[72] Pinto, R C.D.A., Medeiros, A., Padaratz, I.J., Andrade, P.B.: Use of Ultrasound to Estimate Depth of Surface Opening Cracks in Concrete Structures, Ndt.Net, 2010, Available: http://ndt.net/ article/ndtnet/2010/10_Pinto.pdf.

[73] Song, H.W.; Saraswathy, V.: Corrosion Monitoring of Reinforced Concrete Structures - A Review, International Journal of Electrochemical Science, 2 (2007) 1, pp. 1-28.

[74] RILEM TC 154-EMC: Recommendations of RILEM TC 154-EMC: 'Electrochemical Techniques for Measuring Metallic Corrosion'Half-cell potential measurements-Potential mapping on reinforced concrete structures, Materials and Structures, 36 (2003) September, pp. 461-471, http://dx.doi.org/10.1007/ BF02481526.

[75] Andrade, C.: Design and Evalaution of service life through concrete electrical resistivity, , Revista ALCONPAT. 2018. 
[76] Garzon, A.J., Sanchez, J., Andrade, C., Rebolledo, N., Menéndez, E., Fullea, J.: Modification of four point method to measure the concrete electrical resistivity in presence of reinforcing bars, Cement and Concrete Composites, 53 (2014), pp. 249-257, http:// dx.doi.org/10.1016/j.cemconcomp.2014.07.013.

[77] Reichling, K., Raupach, M., Klitzsch, N.: Determination of the distribution of electrical resistivity in reinforced concrete structures using electrical resistivity tomography, Materials and Corrosion, 66 (2015) 8, pp. 763-771, http://dx.doi.org/10.1002/ maco.201407763.

[78] Azarsa, P., Gupta, R.: Electrical Resistivity of Concrete for Durability Evaluation: A Review, Advances in Materials Science and Engineering, 2017, http://dx.doi.org/10.1155/2017/8453095.

[79] Sengul, O.: Use of electrical resistivity as an indicator for durability, Construction and Building Materials, 73 (2014), pp. 434-441, http://dx.doi.org/10.1016/j.conbuildmat.2014.09.077.

[80] Polder, R., Andrade, C., Elsener, B., Vennesland, $\varnothing$., Gulikers, J., Weidert, R., Raupach, M.: Test methods for on site measurement of resistivity of concrete, Materials and Structures, 33 (2000) 10, pp. 603-611, http://dx.doi.org/10.1007/BF02480599.

[81] Proceq, S.A.: Resipod operating instructions, Schewerzenbach, Switzerland, 31. 2011.

[82] Ožbolt, J., Balabanić, G., Kušter, M.: 3D Numerical modelling of steel corrosion in concrete structures, Corrosion Science, 53 (2011) 12, pp. 4166-4177, http://dx.doi.org/10.1016/j.corsci.2011.08.026.

[83] HRN EN 206:2013+A1:2016 Concrete - Specification, performance, production and conformity, Croatian Standards Institute. Zagreb, 2016.
[84] Ožbolt, J., Oršanić, F., Balabanić, G.: Modeling pull-out resistance of corroded reinforcement in concrete: Coupled three-dimensional finite element model, Cement and Concrete Composites, 46 (2014), pp. 41-55, http://dx.doi.org/10.1016/j. cemconcomp.2013.10.014.

[85] Ožbolt, J., Oršanić, F., Balabanić, G.: Modeling influence of hysteretic moisture behavior on distribution of chlorides in concrete, Cement and Concrete Composites, 67 (2016), pp. 7384, http://dx.doi.org/10.1016/j.cemconcomp.2016.01.004.

[86] Ožbolt, J., Oršanić, F., Balabanić, G.: Modeling corrosion-induced damage of reinforced concrete elements with multiple-arranged reinforcement bars, Materials and Corrosion, 67 (2016) 5, pp. 542-552, http://dx.doi.org/10.1002/maco.201508569.

[87] Ožbolt, J., Oršanić, F., Balabanić, G.: Modelling processes related to corrosion of reinforcement in concrete: coupled 3D finite element model, Structure and Infrastructure Engineering, 13 (2017) 1, pp. 135-146, http://dx.doi.org/10.1080/15732479.2016.1198400.

[88] Ožbolt, J., Balabanić, G., Sola, E.: Determination of critical anodic and cathodic areas in corrosion processes of steel reinforcement in concrete, Materials and Corrosion, 68 (2017) 6, pp. 622-631, http://dx.doi.org/10.1002/maco.201609295.

[89] Ožbolt, J., Balabanic, G., Periškic, G., Kušter, M.: Modelling the effect of damage on transport processes in concrete, 24 (2010), pp. 16381648, http://dx.doi.org/10.1016/j.conbuildmat.2010.02.028.

[90] Ožbolt, J., Oršanić, F., Balabanić, G., Kušter, M.: Modeling damage in concrete caused by corrosion of reinforcement: Coupled 3D FE model, International Journal of Fracture, 178 (2012) 1-2, pp. 233244, http://dx.doi.org/10.1007/s10704-012-9774-3.

[91] CodeBRIDGES. Influence of concrete damage on reinforcement corrosion - computer simulation and in-service performance of bridges, https://www.grad.unizg.hr/codebridges, 2019. 